\title{
Stakeholder perception on corporate reputation and management efficiency: Evidence from the Spanish Defence sector
}

\author{
José Solana-Ibáñez ${ }^{1}$ Manuel Caravaca-Garratón ${ }^{2}$ Ricardo Teruel-Sánchez ${ }^{3}$
}

\begin{abstract}
The Spanish Ministry of Defence was the first to elaborate a Social Responsibility (SR) report stating that efficiency plays a leading role. The territorial organs to manage the image and trust in the armed forces, are given by the Spanish Defence Delegations (SDD), and all of them are certified with a seal of excellence. In this work, defence economics and analysis of efficiency line up with the concept of SR. The main aim is to analyse if SR policy has an effective influence and, as a consequence, a high degree of performance can be expected. To this end, given a set of discretionary variables, the efficiency of the 19 SDD during the 2015-2017 period is analysed by means of Data Envelopment Analysis technique. A bootstrap procedure is used to eliminate the bias of the estimates and obtain a robust ranking. The results show an unusual positive behavior in public sector.
\end{abstract}

Keywords: Data Envelopment Analysis (DEA); Bootstrap; Defence Economics; Defence Delegations; Efficiency; Social Responsibility

1Department of Economics and Juridical Sciences, University Centre of Defence at theSpanish Air Force Academy, 30720 Murcia,Spain. Correspondence: jose.solana@cud.upct.es

2 Department of Science and Informatics,University Centre of Defence at the SpanishAir Force Academy, 30720 Murcia, Spain.

${ }^{3}$ Manager of the University Centre of Defenceat the Spanish Air Force Academy, 30720 Murcia, Spain. 


\section{INTRODUCTION}

The social responsibility (SR) of private or public organizations adds a differential competitiveness and a long-term profitability advantage. As is extracted from (Vilanova, Lozano, \& Arenas, 2009), (Marín, Rubio, \& de Maya, 2012), (Marín et al., 2012), (Battaglia \& Frey, 2014), (Boulouta \& Pitelis, 2014), (Herrera Madueño, Larrán Jorge, Martínez Conesa, \& Martínez-Martínez, 2016) or (Godoy, Martins-Rodrigues, da Rosa, Damke, \& Gomes, 2019), this is from the favourable assessment of socially responsible behaviour by the stakeholders, whether natural or legal persons, affected. As a result, the practice of social responsibility has become a clearly relevant factor.

The evolution of the concept of SR is broad and complex (Cochran, 2007), but it refers to ethics as a precept for action, and means a change of mentality and corporate culture. In the public sector sphere, as noted by (Godoy et al., 2019, p. 103), SR implies to promote the transparency with society in an effort to drive sustainable development.

The public administration has advanced in this area but with delay in the implementation of policies compared to private enterprise. In the case of Spain, the Ministry of Defence was the first to elaborate a SR report, presented in October 2010, which included, among other points, the commitments made by this institution in environmental matters. Chapter 1 is entitled "Modern and Efficient" and states that efficiency in the use of resources plays a leading role in the ministry's work at all times. The main Ministry of Defence territorial bodies to manage the image and, by extension, trust in the sector, are given by the SDD, and all of them are certified with a seal of excellence.

It is therefore of interest to analyse the extent to which SDD are efficient in their performance: if the SR policy has an effective influence, a high degree of performance can be expected. This is precisely the main objective and working proposition of this paper, which implies an innovative research connecting defence economics and efficiency analysis areas.

Public sector efficiency has received special attention in recent decades both in the economic and socio-political fields; not in vain, it is the main protagonist of efficiency and productivity analysis research area. The new atmosphere marked by extreme austerity and absence of public resources, has further strengthened its proliferation usually with the suspicion that private incentives to enhance and reinforce efficiency seem to disperse in the case of the public sector.

A main but complex mission of the public administration is to predict social challenges and actively manage them in order to mitigate their impact on families and businesses. A major problem for the success of this task comes, no doubt, from the influence of external trends. Among them, and following (Pollitt, 2016a, 2016b), globalization, demographic, climatic and technological change, the global economic scenario, and the confidence of citizens in the public administration, hinder the anticipation of the emerging changes and force to develop a dose of agility, flexibility and efficiency that affects the organizational structure of public systems. In the Spanish case, in fact, the Commission for the Reform of Public Administrations (CORA) ${ }^{1}$, aimed at "improving the efficiency and effectiveness of public activity, reducing its cost without entailing a decrease in the quality of the services provided".

In a broader context, the last two decades of reforms in the European Union (EU) member states show progress in both the efficiency and effectiveness of Public Administration. This is drawn from the results of the COCOPS project (Coordinating for Cohesion in the Public Sector),

\footnotetext{
${ }^{1}$ Created by Agreement of the Council of Ministers of 10/26/12. For the execution and monitoring, the Office for the Execution of the Administration Reform (OPERA) was created in 2013, regulated by Royal Decree 671/2014, of August 1. See https://administracion.gob.es/pag_Home/ca/espanaAdmon/espanaAdmon/CORA.html
} 
based on 4814 responses in 10 member countries, including Spain, which analyzes the impact of reforms in management and public services that address service needs of citizens and the improvement of social cohesion in Europe during the period 2011-2014 ${ }^{2}$. On the other hand, with a broader objective and greater coverage (34 countries, including the $28 \mathrm{EU}$ member states), the Standard Eurobarometer-85 (EB85) ${ }^{3}$ survey conducted in 2016, assesses the European political situation, main concerns and perception on the institutions and national governments.

As regards the COCOPS project, in the indicator of global evaluation of the public administration, Spain is the only country in the group in which its functioning has been deteriorated over the past 5 years. On average, the reforms related to the internal processes of the sector, i.e., those directed towards the rationalization of inputs and outputs or the improvement of the efficiency and effectiveness of management, show a slight improvement except in the case of Spain, which reaches the lowest value in dimensions such as "cost and efficiency", with a value of 4.17 points on a scale of 1 (significant deterioration) to 7 (significant improvement), or service quality, where Spain occupies the worst position after France. On the other hand, in terms of the dimensions related to the global effects on society, a deterioration in social cohesion, citizen participation and especially in the confidence of citizens in the Government is reported, which worsens in all countries except Norway, with Spain at the head of the most significant deterioration (2.46 points). This last fact is of special relevance since the quality of the public services of a country not only serves as an indicator of the overall good functioning of a State, but also correlates with the level of trust in the public administration ${ }^{4}$.

The EB85 results do not show a very different scenario. Thus, the "current situation of the provision of public services" obtains on average for the group of 34 countries $46 \%$ of negative responses, a figure that, in the case of Spain, amounts to 65\%, only surpassed by Greece, Italy, Romania and Croatia. The score obtained is not the result of a low valuation for the goods and services provided by this sector: $75 \%$ of respondents indicate a positive assessment, i.e., give importance to public services, exceeding the average of the group of countries (64\%). Public services are therefore perceived as important but poorly managed in the case of Spain. In "Public Administration Trust", 48\% of distrust is reported on average, which scales up to 59\% in Spain, the sixth worst rating of the group of countries. Similarly, it happens in terms of "trust in regional or local authorities", with $47 \%$ of distrust and $68 \%$ in the Spanish case, only surpassed by 3 countries. Especially worrying is distrust in the political class: the average trend is $79 \%$ distrust, with Spain being the third most suspicious country (90\% distrust), only surpassed by Greece and France.

Although the results offered by these types of initiatives seem to indicate that some countries of the EU have improved the functioning of their public sector, the pace of social, technological and economic changes requires a dynamic and strict effort for the adaptation process. To face the challenge of a more efficient administration and, by extension, to improve trust in institutions, governments and in the quality and provision of public services, the urgent need for a rational use of resources in the face of difficulties in increasing the level of necessary income, and the efficiency problems of our public sector as a whole, motivate the prominence and interest of works that offer techniques to elucidate or improve the understanding of the phenomenon.

\footnotetext{
${ }^{2}$ See (Hammerschmid et al., 2013).

${ }^{3}$ The results of the survey can be seen in: ttps://data.europa.eu/euodp/es/data/dataset/S2130_85_2_STD85_ENG

${ }^{4}$ See (European Commission, 2018).
} 
In line with that purpose, the public sector has been the main actor in the "Efficiency and Productivity Analysis" area, in which this work is framed. In the development of methodologies for the empirical evaluation of the efficiency of productive units, and from the work of (Charnes, Cooper, \& Rhodes, 1978), the Data Envelopment Analysis (DEA) methodology had precisely the public sector as the leading driver of overflowing growth. The possibilities of empirically analyzing efficiency in the public sphere and the extent to which it was possible to correct and detect inefficiencies, offered an attractive alternative to objectives such as public deficit reduction. In other words, and according to (Lovell, 1994), the objective is not to spend less but to spend better, avoiding waste of resources through their inefficient use. The ability to quantify and evaluate efficiency provides economic and political agents with a control mechanism for monitoring the decision units performance, identify sources of efficiency and from there define policies and action plans.

Within the efficiency literature and, in relation to the public sector, this work engages within the field of defence economics. The interest lies in the fact that the defence of any State has a capital importance when it comes to sustaining its structure, protecting and preserving in this way the peaceful development of the different actors comprising the civil community. If in general assessing public sector performance is a complex phenomenon, it is even more complicated to measure the efficiency of the defence sector in peacetime, since the output produced is difficult to analyze. However, the defence activity, including the most elementary level of preparation for operational actions, is specified in a plurality of needs that, as is customary in the public sector, come into conflict, evidencing the main economic concern: the allocation of scarce resources for alternative demands.

The aforementioned correlation between the level of trust in the public administration and the quality of the public services of a country, also serves as support to justify the relevance of the application to be developed in this work. Indeed, on the one hand, although the distrust in the public administration is notable on average and with special crudeness in Spain, the same does not occur in the defence subsector. The EB85 results in "confidence in the Army" offer a result of $73 \%$ of average confidence for all countries. However, in Spain this value falls to $68 \%$. The main Ministry of Defence territorial bodies to manage the image and, by extension, trust in the sector, are given by the delegations. It is therefore important to analyze the extent to which the Military Administration meets the standards of quality and efficiency, since the impact would not only be economic, but also a positive externality in relation to the image that the Armed Forces project to Spanish society.

Consequently, the efficiency of the 19 SDD during the 2015-2017 period will be analyzed, establishing an unprecedented connection between the efficiency analysis methodology and the scope of the defence economics field. For this purpose, the DEA technique will be explored, applying to the available data models tending to quantify the efficiency of each delegation given a set of discretionary variables (inputs and outputs). A bootstrap procedure is used to eliminate the bias of the efficiency estimates and obtain a robust ranking of the units under evaluation.

Section 2 presents the area of defence economics, scope and evolution as well as the SDD, protagonists of the empirical application. Section 3 addresses the DEA methodology. The empirical application and main results are developed below, in section 4; first, the data sample and units to be evaluated is presented and the results obtained; the data were requested from the delegations through a template with three main sections: actions, personnel and assigned budget. The work concludes with the final chapter dedicated to the conclusions, discussion of the main objectives and results of the analysis, strengths and weaknesses, implications for the enhancement and possible future lines of research. 


\section{DEFENCE ECONOMICS AND EFFICIENCY ANALYSIS}

Consistent with the improvement in the rationality and transparency of public spending, this work relates two main research areas: Defence Economics and Analysis of Efficiency and Productivity. A fundamental weakness in the public administration is the lack of technical concreteness between the desire and express normative declaration of the need to evaluate the achievement of the objectives, and the tools to analyze the application of the assigned financial resources. The DEA methodology assumes the link between the aforementioned areas that are presented and related in this section.

The defence has historically been approached from two perspectives: the economy side and the one derived from the analyzes related to studies in international security. From the first, defence economics emerges in the mid-twentieth century as a research area, driven largely by the peculiarities of defence as a public good and a traditional example of market failure ${ }^{5}$. Following (Hartley \& Sandler, 1995, p. 6) defence economics applies to defence, peace sciences and conflict studies, the topics of resource allocation, income distribution, economic growth and stabilization. Indeed, from the works of (Jones-Lee, 1990), (Intriligator, 1990), (McClelland, 1990), (Reppy, 1991), (Hartley \& Sandler, 2000) or (Hartley, 2012), is extracted both the complexity of content under analysis and the relevance of its study.

According to (Vega, 2015, p. 38), the literature review indicates as main topics of interest those who analyze the relationship between macroeconomics and defence, sectoral industrial policy, efficiency in the composition of forces and in the allocation of resources. In general, much of the effort has focused on the relationship between macroeconomics and defence; specifically, and according to (Martínez González \& Rueda López, 2013, p. 153), in three lines of analysis of the relationship between expenditure and industry: the study of the effects of defence spending on economic growth, the analysis of defence spending determinants, and the economic evaluation of the defence industry.

Nonetheless, defence economics covers both macro and microeconomic aspects and has linkages with industrial and business organization, technology, research and development, environmental economics and public economy. It is in the latter that this work is framed, i.e., with the administrative organization of the defence systems, their repercussions from the point of view of public management, and how it influences effectiveness and efficiency of defence spending. Specifically, with the analysis of the efficiency in processes associated with public policies for planning defence resources, both financial and material and human, that will be applied to the defence delegations of the Spanish territory through the use of the DEA efficiency evaluation methodology.

Once the resources to provide the defence with the necessary capabilities have been allocated, the achievement of the objectives should be assessed. This, in fact, has influenced the evolution of the legal framework of defence planning in Spain, whose origin is settled in the Ministerial Order (MO) (Ministerio de Defensa, 2005) ${ }^{6}$, replaced by MO (Ministerio de Defensa, 2015) ${ }^{7}$. Both classify defence planning into two threads: the military and the resource planning (material, financial and human); however, only the $2015 \mathrm{MO}$ points out the need for "an evaluation referred to the achievement of the objectives. This requires establishing a traceability between the needs to reach the capacities and the application of the financial resources for its achievement". Precisely, the DEA methodology proposed in this work can

\footnotetext{
${ }^{5}$ See (Stiglitz, 1986).

${ }^{6}$ Official Defence Bulletin 68, of April 8, 2005.

${ }^{7}$ Official Defence Bulletin 240, of December 10, 2015.
} 
serve as a tool to analyze whether or not the discrepancy is attributable to management, providing useful information for decision making and strategic planning.

Within the efficiency literature, the public sector has been the driving force for the initial methodological development of a range of analysis techniques. The prominence of the public sector stems from works such as those of (Alchian, 1965), (Niskanen, 1971), (De Alessi, 1974) or (Lindsay, 1976), which point to public managers as capital intensive budget maximizers agents. In the current socio-economic scenario, the reasons for the importance of studies to assess the activity of different areas of the public sector still remain, where, in addition, much of the effort has been directed towards the process of measuring and comparing the performance of productive units. Indeed, on the one hand and following (Levitt \& Joyce, 1987), the mere existence of the public spending does not imply that public administrations are conducting the social objectives that justify it. Secondly, if management inefficiency is detected and improvement measures are undertaken, it will result in a plausible decrease in public spending, a core and basic objective that sustains the public administration management modernization and enhancement projects. Stakeholders, meanwhile, have progressively increased pressures and demand quality in the provision of public services; Finally, there are public spending areas of critical macroeconomic relevance, such as education or defence.

The first formal definitions of efficiency date from (Koopmans, 1951), (Debreu, 1951) and especially (Farrell, 1957), whose pioneering work approached efficiency from a frontier perspective. Indeed, following (Coelli, Rao, \& Battese, 1998), in Economics, two main methods have been addressed for efficiency analysis: non-parametric or frontier models, and parametric or non-frontier models. Thanks to their suitability to the peculiarities of public production, nonparametric ones were adequate for the evaluation of public services ${ }^{8}$, by measuring efficiency in a relative way by comparing the units under evaluation, or DMUs (Decision Making Units), with a standard: the efficient frontier. This is built from the best units and DMU deviations from it serve as a basis for inefficiency measurement. Following (Fried, Lovell, \& Schmidt, 1993), non-parametric approaches, instead of specifying a functional form for the frontier, establish assumptions about production technology to estimate it from the data. They are based on nonstatistical mathematical programming techniques and are especially useful in the public sphere, where it is really difficult to know a priori the form of the underlying frontier relations, and it is necessary to work with information on multiple inputs and outputs.

DEA was first introduced in the literature in (Charnes et al., 1978) $)^{9}$ as an optimization method of mathematical programming to generalize the (Farrell, 1957) single-input/ single-output technical efficiency measure to the multiple-input/ multiple-output case. Thus DEA become a new tool in operational research. Since its introduction, it has been developed and expanded for a variety of areas, which include applications to hospitals, education, military, airlines, and other, and uses in for-profit as well as not-for-profit DMUs.

A main criticism of frontier methods, such as DEA, was its deterministic nature. Among the limitations was its sensitivity to the model specification, the variable selection, the existence of measurement errors and outliers or extreme values and statistical noise. As pointed out by (Simar \& Wilson, 2015), although the statistical properties of the estimator were ignored for years, the advances made since the 1990s made statistical inference possible under the nonparametric approach.

\footnotetext{
${ }^{8}$ Because they allow dealing with aspects such as the absence of a market, the monopolistic nature of public production, the absence of expulsion mechanisms or the need to use market prices, the latter restriction of great initial appeal in the public sector.

${ }^{9}$ The model, known as CCR, was developed under Constant Returns to Scale assumption (CRS) and was extended by (Banker et al., 1984) to include Variable Returns to Scale (VRS): the BCC model.
} 
From the first attempts to develop statistical procedures in (Banker, 1993), the difficulties associated with the use of asymptotic results, pointed to the bootstrap procedure, developed by (Efron, 1979), as the way to approximate the distribution of statistics calculated by the DEA. The bootstrap methods proposed by (Simar \& Wilson, 1998, 2000), derived in the main way of making inference about efficiency based on DEA estimators in settings with multiple inputs and outputs. In addition (Kneip, Simar, \& Wilson, 2008) demonstrate the consistency of bootstrap procedures to make inference.

\subsection{DEA defence literature}

An exhaustive review of the development of the DEA technique throughout its history can be obtained from the works of (Seiford, 1996), (Seiford, 1997), (Gattoufi, Oral, \& Reisman, 2004), (Emrouznejad, Parker, \& Tavares, 2008) and (Emrouznejad \& Yang, 2018). The growth of the area is undoubtedly exponential, with more than 10,000 articles and almost 12,000 authors in the last 40 years ${ }^{10}$.

Applications on DEA in the defence sector have their origin in the works of (Lewin \& Morey, 1981) and (Charnes, Clark, Cooper, \& Golany, 1984) on aircraft recruitment and maintenance, respectively. In spite of the initial expectations, the spread of the area has been scarce and has concentrated interest in a bounded range of defence activities. Following (Hanson, 2016, p. 12), among the reasons they stand out the following: "difficulties in modeling and measuring output in the military; heterogeneity leading to small populations of military units; and restricted access to data".

An extensive though not exhaustive review of DEA literature in defence sector, allows to identify three main research areas. First, the defence industry field, for which table 1a offers some references of works that range from (Bowlin, 1995) to the present time. In general, basic radial-type DEA models are applied, and with exceptions, as in (Martínez González \& Rueda López, 2013), bootstrap techniques are not used.

\section{Insert table 1a}

Secondly, the field of Military Planification was the first to appear and includes applications from different areas: recruitment, maintenance, civil reserveair fleet, weapon systems evaluation, engineering design projects, military retail stores and transport. Table $1 \mathrm{~b}$ contains an illustrative reference collection; although the variety of DEA models is considerably broadened, bootstrap techniques are not used here either.

\section{Insert table $1 b$}

Finally, the Resources Management field covers all those applications on defence resource planning, both financial and material and human, i.e., the field to which the application to be developed in this work is attached. As it is shown in table 1c, there is a concentration of works in the field of health (hospitals, pharmacies, military health institutes). A small number of studies make use of bootstrap techniques as well as other statistical regression techniques to analyze efficiency.

\section{Insert table 1c}

The literature review shows, in the first place, the insufficient length of works on DEA in defence economics, even more reduced in the case of Spain, where no previous work has applied the bootstrap method in order to obtain bias-corrected efficiency scores and a robust DMUs ranking. The foregoing highlights the application proposed in this paper on the SDD

\footnotetext{
${ }^{10}$ See (Emrouznejad \& Yang, 2018, p. 7).
} 
performance analysis. In addition, given the high sensitivity of non-parametric methods to extreme or atypical values (outliers), a previous analysis is carried out in order to detect and control possible atypical behaviors. Also, to determine whether the most appropriate DEA model corresponds to a variable (DEA-VRS) or constant (DEA-CRS) returns to scale, bootstrap-based hypothesis tests are applied.

\section{DATA AND METHODOLOGY}

The main aim of the empirical analysis is to analyze the efficiency in the provision of services of the 19 SDD, including the two autonomous cities, Ceuta and Melilla. On such units, information is collected through questionnaires sent to each one for the years 2015, 2016 and 2017. Likewise, the data relative to the average of the period considered will also be analyzed.

Accordingly, in this section the units to be evaluated will be presented first. Secondly, the relevant variables, inputs and outputs, consistent with the characteristics of the services provided, the type of facilities provided and its quality will be defined. Thirdly, the data will be presented, including the debug phase (null values, missing data, errors, etc.) and outliers analysis, and the methodology used will be briefly discussed.

\subsection{Data and variables}

The units under evaluation are the SDD: territorial bodies created in 1993 in order to establish a unitary peripheral organization of the Ministry of Defence ${ }^{11}$. With its public opening in 1994, a real milestone was launched in the process of modernization of the peripheral structure of defence and its standardisation with that of the rest of the General State Administration. Its structure, based on 19 delegations, 52 sub-delegations and 4 delegated offices, integrates a variety of services with the aim of discharging the Armies from bureaucratic tasks ${ }^{12}$.

It is worth stressing the firm commitment of the Spanish Ministry of Defence with the objective of ensuring that the SDD are reference entities in terms of quality and efficiency of the services they provide, consolidating a modern, efficient and citizen-oriented military administration. If high standards of quality and efficiency are reached, the impact will not only be economic but will produce a positive externality in terms of the image that the Armed Forces project to society.

The main services provided by SDD can be grouped into: common services (promotion and dissemination of the culture of defence, attention to inquiries, complaints and suggestions of citizens); personal and social support; recruitment; heritage and industrial inspection (activities associated with quality inspection and industrial safety).

The commitments of the SDD are aimed at facilitating the exercise of their rights to citizens and ensuring the effective fulfillment of the specific objectives set by the Ministry of Defence, reducing and, in any case, complying with the legally established deadlines. These commitments will serve to define the outputs to be used in the application and can be grouped into 3 types. First, "management agility" (process within a maximum period of 2 working days from its registration, the documentation submitted; deliver the certificates of services provided within a maximum period of 5 working days; answer complaints and suggestions in a maximum period of 15 working days). Secondly, "attention and face-to-face information" (provide inperson citizen attention in a waiting time of less than 10 minutes; answer phone calls with a

\footnotetext{
${ }^{11}$ Created by Royal Legislative Decree (España. Ministerio de Defensa, 1993). The organisation and functioning of the delegations is regulated by the Royal Legislative Decree (España. Ministerio de Defensa, 2007).

${ }^{12}$ See map of defence delegations and sub-delegations in (Ministerio de Defensa, 2019).
} 
wait of less than 1 minute; keep the information on the official bulletin board updated at least once a week); Finally, "attention and information" (answer the requests and inquiries received within a maximum period of 20 working days, counted from the day following the submission of the application).

It should be emphasized that according to (Ministerio de Política Territorial y Función Pública, 2017), all delegations are certified with a seal of excellence by the Agency for the Institute for the Evaluation of Public Policies ${ }^{13}$, with the EFQM Model (European Foundation for Quality Management). Out of 52 provincial sub-delegations, 17 are accredited at level +200 of the EFQM model, 22 at level $+300,8$ at level +400 of the EFQM model and 3 at the highest level, +500 (the sub-delegations in Valladolid, Burgos and Melilla). In 2017 they were also awarded the "crystal seal" for their brilliant management the delegations in Aragon and Murcia, awarded every year to the ten organisations of the General State Administration that have stood out for their level of excellence ${ }^{14}$.

In 2008, the "Service Letters" that the SDD offer to citizens were prepared; they were submitted for review four years later, for the period 2012-15, and again in 2016. These Service Letters appear detailed both on the Internet ${ }^{15}$ and in information leaflets and in them the commitments are established, whose compliance is periodically evaluated by means of the Quality Indicators Report, a source used for empirical application information.

The data required for the SDD were specified in a template (see Appendice I) with three sections: actions, personnel and assigned budget. The actions section was designed in accordance with the fields of the quality report contained in the service letters. Personnel discriminate between civil and military staff; the assigned budget reflects the expenditure of each delegation. This template requested information from 2015 to 2017.

Upon receipt of data, in March 2018, almost 100\% of the requested information was collected. In actions, column "out of term", the number of missing data was considerable. In personnel, $100 \%$ of the information was received without loss of any kind or missing or null data for any of the years or delegations. Finally, in the allocated budget/expenditure, $100 \%$ of the delegations consigned the expenditure, although the same did not occur in the initially allocated budget.

The variable selection, inputs and outputs, is undoubtedly a critical phase on account of its importance to capture the characteristics of the underlying production function. As is usual in empirical efficiency research, this stage of the application has been based on the effective information collected and also in the review of previous similar literature, although here the only antecedent is found in the work of (Martín Casares, 2013) ${ }^{16}$. The definition of discretionary inputs and outputs to be used and their description are summarized in Table 2, and the following Table 3 offers a summary of main statistics for the average data of the period analyzed.

\footnotetext{
${ }^{13}$ Created by Royal Legislative Decree (Ministerio de Hacienda y Función Pública, 2017)

${ }^{14}$ A list of organizations whose level of Excellence has been certified can be obtained at the following link of the Ministry of Territorial Policy and Public Service: https://www.mptfp.gob.es/portal/funcionpublica/gobernanzapublica/calidad.html

15 See the website of the Ministry of Territorial Policy and Public Function, in http://www.seat.mpr.gob.es/portal/delegaciones_gobierno/cartas_servicios.html

${ }^{16}$ In spite of the differences in methodology applied, the author is Lieutenant Colonel of the Intendancy, head of the General Directorate of Economic Affairs of the Ministry of Defence. Given the expert knowledge of the true production frontier that this author can provide, our variable selection has been made in a congruent manner, although not entirely coincident.
} 


\section{Insert table 2}

\section{Insert table 3}

The high sensitivity of non-parametric methods to extreme or atypical values (outliers) requires some kind of preventive analysis, since they can generate bias in the results that would distort the estimation of parameters. Thus, following (Simar, 2003, p. 393): "Detecting outliers is thus of primary importance: it is not an easy task in this multivariate setup". The elimination of the affected unit is always a complex decision; as they point out (Wheelock \& Wilson, 2008, p. 212): "Merely because an outlier is found does not mean it should be deleted. An observation might be atypical because it has a low probability of being observed. In this case, the outlier might be the most interesting part of the data. On the other hand, outliers can also result from measurement errors, coding errors, or other mistakes. When data have been corrupted by such errors, they should be repaired or deleted if correction is not possible. In applied work, however, it is often difficult to identify why an observation is atypical".

Within the efficiency literature, some tools have been developed from the works: (Charnes, Cooper, Golany, Seiford, \& Stutz, 1985), (Torgersen, Førsund, \& Kittelsen, 1996), (Wilson, 1993, 1995) or (Simar, 2003). The work of (Wilson, 1993) extends the statistic of (Andrews \& Pregibon, 1978) for the case of multiple outputs, and, based on the geometric influence function, analyzes the graph of the logarithm of the ratios ${ }^{17}$ :

$$
\log \left[\frac{R_{L}^{i}}{R_{\text {Min }}^{i}}\right]
$$

Examining the log-ratio plot, the separation between the smallest ones will indicate possible outliers. The ratio must be calculated for each possible subset $L$ of size $i$, the choice of the point at which to stop the analysis, $i$, is arbitrary and implies an increase in the computational load of the method for large samples. This procedure has the advantage of not requiring the prior identification of any orientation for the model.

Applying the method to each year, log-ratio figures ${ }^{18}$ are obtained, as shown in Figure 1.

\section{Insert figure 1}

\section{Outlier Analysis. Log-ratio plot}

For each year, the graph shows the smallest values for the log-ratios. The straight line connects the second smallest values for each $i$, thus observing the separation between the lowest values of the ratios for each value of $i$. For values of $i$ where wide jumps occur, the procedure allows to identify the units.

In general, the analysis of the jumps is justified by slight atypicalities not attributable to errors in the data. Thus, for example, for the first year, at $i=2$, the separation observed in Figure 1 corresponds to Ceuta and Melilla, two autonomous cities with a particular and peculiar nature. The jump in $i=7$ points to delegations such as Aragón, which has the maximum at output $y_{3}$, or Asturias, which reaches the maximum at output $y_{2}$. The analysis thus allows a greater degree of knowledge of the structure of the information, pointing out from the beginning those SDD of unequal behavior. In short, a more homogeneous data structure is obtained in the first and

\footnotetext{
17 The numerator is the (Andrews \& Pregibon, 1978) statistitic. If $S=(1,2, \ldots, n)$ is a set of $\mathrm{n}$ units, $\mathrm{L}$ is a similar set of smaller size containing i units such that $\mathrm{L} \subset \mathrm{S}, \mathrm{i}<\mathrm{n}$. The statistic $R_{L}^{i}$ is defined, which represents the geometric volume in the space of inputs and outputs, and encompasses a subset of data where $i$ units have been suppressed in relation to the volume covered by the total data set. The denominator of the ratio represents the minimum value taken by the statistic for all possible subsets $\mathrm{L}$ of size $\mathrm{i}$.

${ }^{18}$ The software (R Core Team, 2018) and the package FEAR (Wilson, 2008) have been used.
} 
last year, and no severe atypicalities are observed in any period or unit evaluated, which will be maintained for the DEA estimate.

\subsection{Methodology}

DEA does not assume a priori a specific functional form of the frontier; instead, given a group of homogeneous DMUs to be evaluated, the set of production possibilities is estimated from the observable input-output combinations, and from the assumptions that determine the properties of the underlying production function ${ }^{19}$.

Let consider a group of $n$ DMUs, $\mathrm{DMU}_{j}$ con $j=1,2, . ., n$. With the aim of establishing the nonparametric characterization of the technology, assume a productive process where a vector of $p$ inputs is used, $x=\left(x_{1}, \ldots, x_{p}\right) \in \mathfrak{R}_{+}^{p}$, to obtain a vector of $q$ outputs, $y=\left(y_{1}, \ldots, y_{q}\right) \in \mathfrak{R}_{+}^{q}$, where:

$$
\Psi=\{(x, y) \mid x \text { can produce } y\}
$$

The set of imaginable and technologically feasible combinations, $\Psi$, can alternatively be defined by the restricted sets of production possibilities, $\chi(y)$ or $\gamma(x)$, according to the requirements in inputs or outputs. Knowing $\chi(\mathrm{y})$ for all $y$, or $\gamma(\mathrm{x})$ for all $\mathrm{x}$, is equivalent to knowing $\Psi$. Thus, in (3) and for an input orientation, $\chi(y)$ collects all combinations that can produce at least $y$ :

$$
\chi(y)=\left\{x \in \mathfrak{R}_{+}^{p} \mid(x, y) \in \Psi\right\}
$$

Designating DMUo to the unit under analysis, in (Charnes et al., 1978) the problem of mathematical programming is presented, whose resolution leads to the measure of efficiency of each unit. This is the input oriented constant returns to scale model, called the DEA-CCR model. Applying the linear conversion of (Charnes \& Cooper, 1962), the authors suggest an equivalent linear programming problem whose dual or enveloping formulation, in (4), offered such an intuitive interpretation that it became popular as a more extended way of considering the technical efficiency estimation:

$$
\operatorname{Min} \theta_{0}
$$

$$
\begin{aligned}
& \text { s.a. } \\
& \sum_{j=1}^{n} x_{i j} \lambda_{i}-x_{i 0} \theta_{0} \leq 0 \quad i=1, \ldots, p \\
& \sum_{j=1}^{n} y_{r j} \lambda_{j} \geq y_{r 0} \quad r=1, \ldots, q \\
& \theta_{0}, \lambda_{j} \geq 0 \quad j=1, \ldots, n
\end{aligned}
$$

For those units that meet the restrictions, the program will assign a non-zero value $\lambda_{j}$, being $\lambda_{j}$ the weights that indicate the ponderation of each efficient unit in the reference set of the unit evaluated.

Value $\theta_{0}$ is the efficiency score of a given unit, $\mathrm{DMU}_{0}$, and expresses the maximum possible equiproportional reduction of the inputs. A unit value means that the unit is over the frontier, $\left(\theta_{0} x_{0}=x_{0}\right)$, and therefore, is technically efficient; when lower than the unit, it will be located below the frontier, $\left(\theta_{0} x_{0}<x_{0}\right)$, and will be considered inefficient. In this case, there will exist

\footnotetext{
${ }^{19}$ See (Thanassoulis, 2001), (William W. Cooper, Seiford, \& Tone, 2007) or (Osman, Anouze, \& Emrouznejad, 2014)
} 
a real or virtual reference DMU (convex combination of other efficient DMUs) that sets the performance guidelines for the inefficient DMU to reach the frontier, indicating $\theta$ the proportion by which the consumption of inputs must be reduced preserving the same level of outputs.

The measures based on (Farrell, 1957) could present slacks, $\left(s_{i}^{-}, s_{r}^{+}\right)$, where $s_{i}^{-}$are the input slack variables (they represent the excess in the amount of inputs), and $s_{r}^{+}$, the output slack variables (collect the defect in the number of outputs). An alternative linear program with slack variables is then through $(5)^{20}$ :

$$
\begin{aligned}
& \quad \operatorname{Min} \theta_{0}-\varepsilon\left(\sum_{r} s_{r}^{+}+\sum_{i} s_{i}^{-}\right) \\
& \text {s.a. } \\
& \sum_{j=1}^{n} x_{i j} \lambda_{i}+s_{i}^{-}=\theta_{0} x_{i 0} \quad i=1, \ldots, p \\
& \sum_{j=1}^{n} y_{r j} \lambda_{j}-s_{r}^{+}=y_{r 0} \quad r=1, \ldots, q \\
& \lambda_{j}, s_{i}^{-}, s_{r}^{+} \geq 0 \quad \forall j, i, r
\end{aligned}
$$

Units with unitary coefficient whose sum of slack variables are non-zero are weakly efficient, since it is still possible to reduce the use of some input without increasing any other; those units for which, in addition to a unit coefficient, the sum of the slacks is zero will be considered efficient in the sense of (Koopmans, 1951).

From (Banker, Charnes, \& Cooper, 1984) the first extension is proposed to include variable returns to scale (VRS), named BCC model or DEA-VRS; its convexity restriction, $\sum_{j=1}^{n} \lambda_{i}=1$, allowed to obtain the pure technical efficiency measure that avoided the effect of scale efficiency. In (Färe \& Grosskopf, 1985), authors propose a method to calculate the scale efficiency by establishing non-increasing returns to scale (NIRS), $\sum_{j=1}^{n} \lambda_{i} \leq 1$, called DEANIRS model.

However, and following (Wheelock \& Wilson, 2008, p. 215), the initial DEA estimators are biased: "The DEA frontier estimate is nothing more than a biased estimate of the true, but unobserved, frontier". Therefore: "it may well be possible for a DMU to significantly reduce its input-usage without reducing output". Consequently, whether or not the efficiency obtained from the basic DEA models reflects the true value depends on the statistical properties of the estimator.

In (Simar \& Wilson, 1998) the authors apply bootstrap techniques to the DEA-VRS estimates and in (Simar \& Wilson, 2000) they extend the initial, more restrictive model, allowing greater heterogeneity in the structure of efficiency. Once the $B$ bootstrap estimates are obtained for a certain unit, $\hat{\theta}_{b}^{*}(x, y)$, the bootstrap bias estimate for the original estimator, $\hat{\theta}(x, y)$, can be calculated using (6):

$$
\operatorname{seŝgo}_{B}(\hat{\theta}(x, y))=\frac{1}{B} \sum_{b=1}^{B} \hat{\theta}_{b}^{*}(x, y)-\hat{\theta}(x, y)
$$

This bias will be analogous to the original estimator bias with respect to the true value of the efficiency, $\theta(x, y)$. Thus, in (7), the bias-corrected estimator of $\theta(x, y)$ can be computed as:

\footnotetext{
${ }^{20}$ See (Ali \& Seiford, 1993), (Coelli et al., 1998) and (W W Cooper, Seiford, \& Zhu, 2011).
} 


$$
\hat{\hat{\theta}}(x, y)=\hat{\theta}(x, y)-\operatorname{se\hat {sgo}}(\hat{\theta}(x, y))
$$

The correction is made for each unit of the sample depending on the size of the mean square error $^{21}$ and the values of $\hat{\theta}_{b}^{*}(x, y)$ can be used to estimate confidence intervals.

To apply bootstrap methods to DEA estimates, it is crucial to use the appropriate model. Usually in empirical applications, the assumption about the scale of returns is proposed intuitively, justifying its relevance in theoretical terms or on the basis of previous literature. In this work, we will use bootstrap-based hypothesis contrasts: we will apply statistic 48 of (Simar \& Wilson, 2011a), equivalent to statistic 4.6 of (Simar \& Wilson, 2002). The procedure allows solving a first null hypothesis test: $\mathrm{H}_{0}=\mathrm{CRS}$, with the alternative $\mathrm{H}_{1}=\mathrm{VRS}$; in the second, these hypotheses are $\mathrm{H}_{0}=\mathrm{NIRS}$ versus $\mathrm{H}_{1}=$ VRS.

\section{RESULS}

\subsection{DEA efficiency estimates}

We deal in the first place with the calculation of the efficiency coefficients of the SDD through the non-parametric DEA technique. For this, the discretionary variables, inputs and outputs are considered according to the information in Table 2. An orientation towards minimizing the input will be used whose convenience is widely collected in the literature for the case of the public sector. Thus, for example, (Worthington \& Dollery, 2001) point out that at least in the short term, public decision units cannot easily control the level of outputs and have greater control over inputs, especially in functional areas.

The DEA-CRS and DEA-VRS models will be solved. Additionally, in order to consider the scale of the returns of each DMU as well as the scale efficiency, the coefficients are also calculated by means of the DEA-NIRS model.

Tables from $4 \mathrm{a}$ to $4 \mathrm{c}$ contain the efficiency coefficients for each year, delegation and model (CRS, VRS, NIRS columns), also including the scale efficiency (column EE) and the scale of returns for each unit (column RTS: DRS for non-increasing returns to scale; CRS for constant, and IRS for increasing). The values appear ordered from highest to lowest efficiency according to the DEA-VRS model.

\section{Insert table $4 a$}

According to Table 4a, under the DEA-CRS model, a total of 9 SDD are efficient in 2015; the resource use by units is therefore optimal in the Debreu-Farrell sense. The minimum efficiency is 0.3198 (Catalonia), which is interpreted as meaning that the delegation should reduce equiproportionally the inputs by $68.02 \%$, considering all the deviation as technical inefficiency. If the values of the inputs for such SDD are analyzed, it is observed that it is the third delegation with the highest expenditure figure; its personnel is also above the average for the year considered, specifically it is the 7th SDD with the largest workforce. However, its results in the outputs are relatively lower (position 13 for output $y_{1}, 11$ for $y_{2}, 13$ for $y_{3}$ and $y_{4}, 11$ for $y_{5}, 12$ for $\left.y_{6}\right)$.

Under variable returns to scale, VRS, the group of 9 efficient SDD under CRS, is increased by 3 more joining: Andalusia, Extremadura and the Basque Country. This is an expected result

\footnotetext{
${ }^{21}$ (Simar \& Wilson, 2000) warn that this correction may increase the noise of the estimate and therefore do not advise rectification if the average quadratic error of the corrected estimator exceeds that of the original estimator. Specifically, they do not recommend modification unless the variance of the original estimator is less than onethird of the square of the estimated bias.
} 
since the VRS frontier envelops the data more narrowly and there are more units that reach it. The minimum value is still belonging to the SDD of Catalonia, 0.4448.

The scale efficiency (EE), rate between the CRS and VRS coefficients, informs about which SDD operate at an optimum scale, and the calculation of the DEA-NIRS coefficients allows obtaining the returns type. Among the 10 SDD that are not CCR efficient, 7 show increasing returns to scale (IRS), that is, they have an excessive dimension or are too large, while the remaining 3 SDD show decreasing returns to scale (DRS).

\section{Insert table $4 b$}

Table 4 b provides the results for 2016. The number of SDD CRS efficient drops from 9 to 8. Cantabria and Castilla la Mancha leave the efficient group and Castilla León enters. A total of 7 SDD retain efficiency in 2016 under the DEA-CRS model. Catalonia goes from an efficiency of 0.3198 in 2015 to 0.377 in 2016, leaving the last position occupied now by the Basque Country, with a coefficient of 0.1801 in 2016 compared to 0.5703 in the previous year.

Regarding the VRS model, 13 SDD are efficient in 2016, one more than the previous year. The Basque Country leaves the efficient group and La Rioja and Castilla León enter. The minimum value continues to belong to the Basque Country SDD with 0.3915.

Concerning the EE, 8 SDD (the efficient ones under CRS) are efficient in all three models; they present technical and scale efficiency; the remaining 11 SDD show scale inefficiency (EE <1). Among them, 10 DDs show increasing returns (IRS) while 1 DD shows decreasing returns (DRS).

\section{Insert table $4 c$}

Table 4c contains the information for the year 2017. A total of 5 SDD are CRS efficient. The Canary Islands, Castilla y León and Valencia leave the group with respect to the previous year. The minimum value corresponds to the Basque Country, whose coefficient falls from 0.1801 in 2016 to 0.11937 in 2017, followed by Murcia, which occupied the 16th position both in 2015 and 2016 and in 2017 it ranks 18th.

Considering the VRS model, the 13 efficient SDD in 2016 become 9 in 2017, 4 less than the previous year: Canarias, Castilla la Mancha, Castilla León and Valencia leave the efficient group. The minimum still belongs to the Basque Country, with 0.53987 .

As for the EE, 5 SDD (the efficient ones under CRS) are efficient in all three models; they present technical and scale efficiency; the remaining 14 SDD show scale inefficiency (EE <1). Of these, 13 exhibit increasing returns (IRS) while 1 DD shows decreasing returns (DRS).

Table 5 below provides a summary of the main information for the three years under consideration. A main result of synthesis is the high and increasing level of average efficiency exhibited by the SDD. Indeed, despite budgetary constraints, the average VRS efficiency has evolved favourably since 2015 , with $86.7 \%$, rising to $87.2 \%$ in 2016 and reaching $87.9 \%$ in 2017. Thus, the average of the 3 years analyzed offers a value of $87.3 \%$. From the point of view of the CRS model, in which each SDD is compared with the others regardless of the scale of returns under which it operates, the evolution of the average efficiency of each year is decreasing (77.6\% in 2015; 73.7\% in 2016 and 70.1\% in 2017), although the average efficiency of the 3 years still reaches a high value: $73.8 \%$ of overall efficiency.

Considering the 3 years, a total of 5 SDD are efficient under all DEA models: Aragón, Asturias, Baleares, Madrid and Melilla. On the side of the inefficient, Catalonia, Galicia and Murcia are placed every year in that group. Between 2015 and 2016, we observe that all SDD maintain (11 SDD) or improve (7 SDD) their situation, with the exception of the Basque Country SDD. In 
the 2016-2017 period, 13 SDD maintain (9 SDD) or improve (4 SDD) their situation, while 6 worsened (Canary Islands, Castilla La Mancha, Castilla León, Ceuta, Murcia and Valencia). Finally, if we consider both interannual periods, 2015-2016 and 2016-2017, 3 SDD evolve improving their situation: Catalonia, Galicia and Navarra.

\section{Insert table 5}

\subsection{Returns to scale test}

From (Simar A \& Wilson, 2011a) and for each year, contrast-1 is solved ${ }^{22}$, that is, CRS vs. RSV and contrast-2, NIRS vs. VRS. Following the procedure described by the authors, the number of bootstrap replications $B=100$ will be used, and the usual value for $\alpha=0,05$.

The results are given in tables $6 \mathrm{a}$ to $6 \mathrm{c}$. The contrast- 1 for the year 2015 , indicates that $\mathrm{H}_{0}$ should not be rejected. Therefore, they point to a CRS scale. However, in view of the critical value ( $p$-value $48=0.06$ ), the VRS scale could be admitted from that level, that is, from a value of $\alpha=6 \%$ the CRS scale would be rejected in favor of the VRS. Contrast-2 rejects $\mathrm{H}_{0}$ for $\alpha=$ $5 \%$, in favor of the VRS scale. In conclusion, the results for the year 2015, suggest the convenience of using the VRS scale. For the years 2016 and 2017 respectively, with $\alpha=5 \%$, the p-values are much lower, between 0.01 and 0.03 , again suggesting a VRS scale.

Consequently, for the final phase of the application, the focus will be placed on the DEA-VRS model.

\section{Insert table $6 a$}

\section{Insert table $6 b$}

\section{Insert table $6 \mathrm{c}$}

\subsection{Bias correction: robust DEA efficiency}

If we consider the real underlying process, it is quite unlikely that there are DMUs with unit coefficients; in the words of (Simar \& Wilson, 2011b, p. 210): "It is clear that the mass of estimates equal to one are due to the bias of the DEA frontier estimator. In other words, the estimates equal to one are spurious. If one were able to observe a sample of true efficiencies, one would not see a group of values equal to one ". Consequently, and in order to consider the stochastic nature of the estimation problem, we will apply the bootstrap procedure of (Simar \& Wilson, 1998, 2000) in order to correct the bias in the estimates of the (Shephard, 1970) type efficiency coefficients, estimating confidence intervals at the same time. This correction will offer a robust and, hence, more complete arrangement of the SDD than that offered by the radial models.

Tables $7 \mathrm{a}$ to $7 \mathrm{c}$ contain the information corresponding to each year for the 19 SDD ordered from highest to lowest efficiency according to the DEAS-VRS coefficients. The DEA-VRS column shows the estimated coefficients according to the definition of (Shephard, 1970). The next column contains the bias calculated using the bootstrap procedure. Based on these two columns, unbiased DEA-VRS contains the unbiased coefficients and serves as a column for the ordering of the table from least (most efficient) to greatest (least efficient). Finally, the last three columns show the statistical inference data, that is, the estimated variance, the lower limit (LI) and the upper limit (LS) of the 95\% confidence intervals, which define the statistical location of the measurement of real efficiency.

\footnotetext{
${ }^{22}$ For the calculation, the command "rts.test" from the rDEA library developed by (Simm \& Besstremyannaya, 2016) has been used.
} 
The results of table 7a reveal the sensitivity of the measurements to the sample variation. In all cases the efficiency of the SDD falls. In terms of (Farrell, 1957) and on average for 2015, efficiency reaches a value of $80.4 \%$ according to the original model (biased). Once the bias is eliminated, the average efficiency drops to $68.5 \%$. Thus, the Madrid SDD, efficient according to the biased DEA-VRS model, now has an unbiased coefficient of 1.222, i.e., that SDD should reduce the consumption of its inputs by $22.2 \%$ and continue producing the same output level. We note that the ordering of the SDD remains unchanged in the inefficient group, although it is now possible to discriminate between the efficient ones given the absence of unit values.

\section{Insert table $7 a$}

Table $7 \mathrm{~b}$ presents the results for 2016. In terms of Farrell and on average for 2016, efficiency remains at $68.5 \%$ according to the corrected (unbiased) model. Again, the ordering of SDD remains unchanged in the inefficient group and the unbiased model allows discriminating between the group of efficient SDD.

\section{Insert table $7 b$}

Thirdly, table 7c shows the results for the year 2017. On average, efficiency increases considerably, rising to $75.6 \%$. On this occasion, the ranking within the inefficient group shows different results. Thus, the SDD of Castilla la Mancha, inefficient according to the DEA-VRS model, presents the best performance of all SDD with an unbiased coefficient of 1.103.

\section{Insert table $7 c$}

Finally, from the annual position occupied by each SDD according to the unbiased DEA-VRS model, the evolution of each individual SDD is observed throughout the period. In general, there is a group of SDD that improve their position annually: Baleares, Cantabria, Castilla la Mancha, Castilla León, Cataluña, Galicia, Navarra and La Rioja. On the other hand, the group consisting of Andalusia, Asturias, the Canary Islands, Extremadura, Murcia, the Basque Country and Valencia, lose position year after year.

\section{CONCLUSIONS}

In this work two prominent areas of research line up: Defence Economics and Analysis of Efficiency and Productivity, with the aim of analyzing if the SR policy has an effective influence and, as a consequence, a high degree of performance can be expected. To this end, the SDD efficiency during the 2015-2017 period has been analyzed using the DEA methodology, an empirical application certainly unprecedented at the national level, for which there are no precedents in the previous literature except for the aforementioned work of (Martín Casares, 2013).

Spain's deficit and public debt problems have highlighted the imperative need to rationalize public resources. This requirement has been translated into different actions by our governors, which include the reform of public administrations since 2012. The requirement of preserving and improving the efficiency of public services, has finally served as motivation for the realization of this investigation.

The commitment of the Ministry of Defence to make the defence delegations a reference for the remaining public administrations came even prior to the beginning of the public sector reform. Through the Undersecretariat of Defence, it has understood from the outset that a quality and efficient military Administration projects our society a reflection of what its Armed Forces represent. Thus, the SDD acquired commitments synthesized in 8 indicators included in the service letters, which are further measurable and collected in annual statistics. This investigation had such data available, collected by the 19 delegations extremely fast. 
The delegations have at the present time a strategic importance in our defence. For more than 20 years, these bodies have been a benchmark for excellence thanks to their constant desire for innovation, which has resulted in the constant improvement of the services provided to the citizen. Despite the difficulties, the defence delegations have not only been able to maintain a considerably high average efficiency, but also have managed to raise it from $68.5 \%$ in 2015 and 2016 to $75.6 \%$ in 2017 . The trend follows, therefore, a consistent path marked by exemplary performance, an unusual positive behavior in the public sector, which consolidates them as a standard for efficiency and quality.

The European Commission's statement on the correlation between the quality of public services and the level of trust in the public administration has served as support, main objective and justification for the relevance of the application developed. Indeed, on the one hand, SDD are the territorial body of the Ministry of Defence that manages the image and, by extension, trust in the sector. On the other hand, according to the EB85 results, Spain's score in "confidence in the Army" is 5 points below the average for all countries.

However, this work obtains as a more outstanding and main result that, in the case of Spain, the superior distrust in the Army is not the result of a low quality of the services provided. One possibility is that the high general distrust in the Spanish public administration, 11 points worse than the average and the sixth worst rating of the group of countries, exerts a gregarious effect, or negative dragging effect, on the defence sector. In any case, the positive externality of an efficient management for the image projected by the Armed Forces to civil society seems to be truncated in the case of Spain.

An area of significance for the proper interpretation of efficiency is the presence of exogenous variables: in fact, implicitly it has been considered that the result obtained by each SDD is due to management efficiency; however, the units performance may be determined by the possible influence of non-controllable variables but influencing the distance to the efficient boundary. Consequently, an efficiency determinants analysis would be mandatory in strictly financial or cost control studies. The main complexity here is the statistical significance of such variables and therefore a further future line of research is to analyze the possibilities offered by the stability analysis.

Naturally, the above conclusions should be relativized as they depend on the precision with which the true nature of the production function is captured. The most problematic part here is the acuracity in the selection of input and output variables. Notwithstanding the limitations outlined above, the paper provides information that may be useful for Spain's defence sector in terms of future strategic planning.

\section{REFERENCES}

Alchian, A. A. (1965). Some economics of property rights. Economic Forces at Work, 30(4), 127-149. https://doi.org/10.1086/467005.

Ali, A. I., \& Seiford, L. M. (1993). Computational Accuracy and Infinitesimals In Data Envelopment Analysis. INFOR: Information Systems and Operational Research, 31(4), 290-297. https://doi.org/10.1080/03155986.1993.11732232

Andrews, D. F., \& Pregibon, D. (1978). Finding the Outliers that Matter. Journal of the Royal Statistical Society, Series B (Methodological), 40(1), 85-93. https://doi.org/10.2307/2984869

Banker, R. D. (1993). Maximum Likelihood, Consistency and Data Envelopment Analysis: A Statistical Foundation. Management Science, 39(10), 1265-1273.

https://doi.org/10.1287/mnsc.39.10.1265 
Banker, R. D., Charnes, A., \& Cooper, W. W. (1984). Some Models for Estimating Technical and Scale Inefficiencies in Data Envelopment Analysis Some Models For Estimating Technical And Scale Inefficiencies In Data Envelopment Analysis *. Management Science, 30(9), 1078-1092. https://doi.org/10.1287/mnsc.30.9.1078

Barros, C. P. (2002). Small countries and the consolidation of the European defence industry: Portugal as a case study. Defence and Peace Economics. https://doi.org/10.1080/10242690212359

Bastian, N. D., Kang, H., Griffin, P. M., \& Fulton, L. V. (2016). Measuring the effect of payfor-performance financial incentives on hospital efficiency in the military health system. IIE Transactions on Healthcare Systems Engineering, 6(1), 33-41. https://doi.org/10.1080/19488300.2015.1132488

Battaglia, M., \& Frey, M. (2014). Public policies of promotion of CSR amongst SMEs and effects on competitiveness: The case of Tuscany region. International Journal of Business Governance and Ethics. https://doi.org/10.1504/IJBGE.2014.062762

Boulouta, I., \& Pitelis, C. N. (2014). Who Needs CSR? The Impact of Corporate Social Responsibility on National Competitiveness. Journal of Business Ethics. https://doi.org/10.1007/s10551-013-1633-2

Bowlin, W. F. (1987). Evaluating the efficiency of us air force real-property maintenance activities. Journal of the Operational Research Society. https://doi.org/10.1057/jors.1987.25

Bowlin, W. F. (1989). An intertemporal assesment of the efficiency of air force accounting and finance offices. Research in Governamental and Nonprofit Accounting, 5(Journal Article), 293-310.

Bowlin, W. F. (1995). A characterization of the financial condition of the United States' aerospace-defense industrial base. Omega, 23(5), 539-555. https://doi.org/10.1016/03050483(95)00032-J

Bowlin, W. F. (1999). An analysis of the financial performance of defense business segments using data envelopment analysis. Journal of Accounting and Public Policy, 18(4-5), 287-310. https://doi.org/10.1016/S0278-4254(99)00018-6

Bowlin, W. F. (2004). Financial analysis of civil reserve air fleet participants using data envelopment analysis. European Journal of Operational Research. https://doi.org/10.1016/S0377-2217(02)00814-7

Brence, J. R., Kwinn, M. J., \& Thomas, D. A. (2007). A holistic approach to U.S. Army recruiting input allocation. Military Operations Research. https://doi.org/10.5711/morj.12.2.5

Brockett, P., Cooper, W. W., Golden, L. L., Kumbhakar, S. C., Kwinn, M. J., Layton, B., \& Parker, B. R. (2008). Estimating elasticities with frontier and other regressions in evaluating two advertising strategies for US Army recruiting. Socio-Economic Planning Sciences, 42(1), 1-17. https://doi.org/10.1016/j.seps.2007.07.001

Brockett, P., Cooper, W. W., Kumbhakar, S. C., Kwinn, M. J., \& McCarthy, D. (2004). Alternative statistical regression studies of the effects of Joint and Service Specific advertising on military recruitment. Journal of the Operational Research Society, 55(10), 1039-1048. https://doi.org/10.1057/palgrave.jors.2601737

Charnes, A., Clark, C. T., Cooper, W. W., \& Golany, B. (1984). A developmental study of data envelopment analysis in measuring the efficiency of maintenance units in the U.S. 
air forces. Annals of Operations Research, 2(1), 95-112.

https://doi.org/10.1007/BF01874734

Charnes, A., \& Cooper, W. W. (1962). Programming with linear fractional functionals. Naval Research Logistics Quarterly, 9(3-4), 181-186. https://doi.org/10.1002/nav.3800090303

Charnes, A., Cooper, W. W., Golany, B., Seiford, L., \& Stutz, J. (1985). Foundations of Data Envelopment Analysis for Pareto-Koopmans Efficienct Empirical Production Functions. Journal of Econometrics, 30, 91-107.

Charnes, A., Cooper, W. W., \& Rhodes, E. (1978). Measuring the efficiency of decision making units. European Journal of Operational Research, 2(6), 429-444. https://doi.org/10.1016/0377-2217(78)90138-8

Choi, J.-H. Y.-W. M. S.-W. (2018). Efficiency Evaluation of Defence Industry Firms by Utilizing DEA. Journal of the Korea Academia-Industrial Cooperation Society, 19(9), 501-507. https://doi.org/10.5762/KAIS.2018.19.9.501

Clarke, R. L. (1992). Evaluating USAF Vehicle Maintenance Productivity Over Time: An Application of Data Envelopment Analysis. Decision Sciences. https://doi.org/10.1111/j.1540-5915.1992.tb00395.x

Cochran, P. L. (2007). The evolution of corporate social responsibility. Business Horizons. https://doi.org/10.1016/j.bushor.2007.06.004

Coelli, T., Rao, D. S. P., \& Battese, G. E. (1998). An Introduction to Efficiency and Productivity Analysis. An Introduction to Efficiency and Productivity Analysis. https://doi.org/10.1007/978-1-4615-5493-6

Cooper, W W, Seiford, L. M., \& Zhu, J. (2011). Handbook on Data Envelopment Analysis. International Series in Operations Research \& Management Science (Vol. 164). Springer. https://doi.org/10.1007/978-1-4419-6151-8

Cooper, William W., Seiford, L. M., \& Tone, K. (2007). Data envelopment analysis: A comprehensive text with models, applications, references and DEA-solver software: Second edition. Data Envelopment Analysis: A Comprehensive Text with Models, Applications, References and DEA-Solver Software: Second Edition. https://doi.org/10.1007/978-0-387-45283-8

De Alessi, L. (1974). An Economic analysis of Government Ownership and Regulation: Theory and the Evidence from the Electric Power Industry. Public Choice, 19, 1-42. https://doi.org/10.2307/30022757

Debreu, G. (1951). The Coefficient of Resource Utilization. Econometrica, 19(3), 273. https://doi.org/10.2307/1906814

Efron, B. (1979). Bootstrap Methods: Another Look at the Jackknife. The Annals of Statistics, 7(1), 1-26. https://doi.org/10.1214/aos/1176344552

Emrouznejad, A., Parker, B. R., \& Tavares, G. (2008). Evaluation of research in efficiency and productivity: A survey and analysis of the first 30 years of scholarly literature in DEA. Socio-Economic Planning Sciences, 42(3), 151-157. https://doi.org/10.1016/j.seps.2007.07.002

Emrouznejad, A., \& Yang, G. liang. (2018). A survey and analysis of the first 40 years of scholarly literature in DEA: 1978-2016. Socio-Economic Planning Sciences, 61, 4-8. https://doi.org/10.1016/j.seps.2017.01.008

España. Ministerio de Defensa. (1993). Real Decreto 2206/1993, de 17 de diciembre, por el 
que se crean las Delegaciones de Defensa. Boletín Oficial Del Estado, (305, 22 diciembre 1993), 36558-36560.

España. Ministerio de Defensa. (2007). Real Decreto 308/2007, de 2 de marzo sobre organización y funcionamiento de las Delegaciones de Defensa. Boletín Oficial Del Estado, (64, 15 de marzo de 2007), 11023-11027.

European Commission. (2018). A comparative overview of public administration characteristics and performance in EU28. https://doi.org/10.2767/13319

Färe, R., \& Grosskopf, S. (1985). A Nonparametric Cost Approach to Scale Efficiency. The Scandinavian Journal of Economics, 87(4), 594-604. https://doi.org/10.2307/3439974

Farrell, M. J. (1957). The Measurement of Productive Efficiency. Journal of the Royal Statistical Society. Series A (General), 120(3), 253. https://doi.org/10.2307/2343100

Farris, J. A., Groesbeck, R. L., Van Aken, E. M., \& Letens, G. (2006). Evaluating the relative performance of engineering design projects: A case study using data envelopment analysis. IEEE Transactions on Engineering Management. https://doi.org/10.1109/TEM.2006.878100

Fonfría, A., \& Duch-Brown, N. (2014). Explaining Export Performance in the Spanish Defense Industry. Defence and Peace Economics, 25(1), 51-67. https://doi.org/10.1080/10242694.2013.857460

Fried, H. O., Lovell, C. A. K., \& Schmidt, S. S. (1993). The Measurment of Productive Efficiency-Techniques and Applications. Oxford University Press.

Fulton, L., Lasdon, L. S., \& McDaniel, R. R. (2007). Cost Drivers and Resource Allocation in Military Health Care Systems. Military Medicine, 172(3), 244-249. https://doi.org/10.7205/milmed.172.3.244

Gattoufi, S., Oral, M., \& Reisman, A. (2004). Data envelopment analysis literature: A bibliography update (1951-2001). Socio-Economic Planning Sciences. https://doi.org/10.1016/S0038-0121(03)00023-5

Godoy, T. P., Martins-Rodrigues, M. C., da Rosa, L. A. B., Damke, L. I., \& Gomes, C. M. (2019). Ethics and social responsibility: A bibliometric study of document production based on Web of Science in the period of 2006 to 2016. Environmental Quality Management. https://doi.org/10.1002/tqem.21642

Hammerschmid, G., Van De Walle, S., Andrews, R., Bezes, P., Görnitz, A., Oprisor, A., \& Štimac, V. (2013). Public Administration Reform in Europe-Views and Experiences from Senior Executives in 10 Countries. Retrieved from www.cocops.eu

Hanson, T. (2016). Efficiency and productivity in the operational units of the armed forces: A Norwegian example. International Journal of Production Economics. https://doi.org/10.1016/j.ijpe.2016.05.016

Harrison, J. P., \& Ogniewski, R. J. (2005). An Efficiency Analysis of Veterans Health Administration Hospitals. Military Medicine, 170(7), 607-611. https://doi.org/10.7205/milmed.170.7.607

Hartley, K. (2012). The economics of defence policy: A new perspective. The Economics of Defence Policy: A New Perspective. https://doi.org/10.4324/9780203838778

Hartley, K., \& Sandler, T. (1995). Chapter 1 Introduction. Handbook of Defense Economics. https://doi.org/10.1016/S1574-0013(05)80003-1 
Hartley, K., \& Sandler, T. (2000). Defence and peace economics: A ten-year retrospective. Defence and Peace Economics. https://doi.org/10.1080/10430710008404935

Herrera Madueño, J., Larrán Jorge, M., Martínez Conesa, I., \& Martínez-Martínez, D. (2016). Relationship between corporate social responsibility and competitive performance in Spanish SMEs: Empirical evidence from a stakeholders' perspective. BRQ Business Research Quarterly. https://doi.org/10.1016/j.brq.2015.06.002

Huo, H., Zhang, X. D., \& Shu, L. X. (2006). Data envelopment analysis in evaluation of resource allocation efficiency in military institute for drug and instrument control. Academic Journal of Second Military Medical University.

Intriligator, M. D. (1990). On the nature and scope of defence economics. Defence Economics. https://doi.org/10.1080/10430719008404646

Jeon, G., \& Yoo, H. (2019). An Efficiency Analysis of Supply Chain Quality Management Using the Multi-stage DEA Model: Focused on the Domestic Defense Industry Companies. Journal of the Korean Society for Quality Management, 47(1), 163-186. https://doi.org/10.7469/JKSQM.2019.47.1.163

Jones-Lee, M. W. (1990). Defence expenditure and the economics of safety: Reply. Defence Economics. https://doi.org/10.1080/10430719008404680

Juan, W., Huapu, L., Xu, S., Xianfeng, L., \& Huijun, Y. (2014). The best path analysis in military highway transport based on DEA and multiobjective fuzzy decision-making. Mathematical Problems in Engineering. https://doi.org/10.1155/2014/206024

Kneip, A., Simar, L., \& Wilson, P. W. (2008). Asymptotics and Consistent Bootstraps for DEA Estimators in Nonparametric Frontier Models. Econometric Theory, 24(6), $1663-$ 1697. https://doi.org/10.1017/S0266466608080651

Koopmans, T. C. (1951). Analysis of production as an efficient of activities. Activity Analysis of Production and Allocation, John Wiley, 33-97.

Lee, D. (2006). Toward a way to enhance organizational effectiveness in the defense sector: Associating CVF with DEA. Korean Journal of Defense Analysis, 18(1), 135-159. https://doi.org/10.1080/10163270609464102

Levitt, M. S., \& Joyce, M. A. S. (1987). The growth and efficiency of public spending. The National Institute of Economic and Social Research, Occasional Papers XLI, Cambridge(Journal Article).

Lewin, A. Y., \& Morey, R. C. (1981). Measuring the relative efficiency and the output potential of public sector organisations: an application of data envelopment analysis. International Journal of Policy Analysis and Information Systems, 5(4)(Journal Article), 267-285.

Lindsay, C. M. (1976). A Theory of Government Enterprise. Journal of Political Economy, 84(5), 1061-1077. https://doi.org/10.1086/260496

Lovell, C. A. K. (1994). Linear programming approaches to the measurement and analysis of productive efficiency, (Journal Article), 243-267.

Lu, W.-M., \& Chen, M. H. (2011). A benchmark-learning roadmap for the Military Finance Center. Mathematical and Computer Modelling, 53(9-10), 1833-1843. https://doi.org/10.1016/j.mcm.2011.01.003

Marín, L., Rubio, A., \& de Maya, S. R. (2012). Competitiveness as a Strategic Outcome of Corporate Social Responsibility. Corporate Social Responsibility and Environmental 
Management. https://doi.org/10.1002/csr.1288

Martín Casares, G. (2013). Modelos de Gestión de la Economía Pública: Caso concreto de la Economía de la Defensa. In I Jornadas sobre "La Cultura de la Responsabilidad Social en las FAS” (pp. 1-53). Granada.

Martínez González, A., \& Rueda López, N. (2013). A productivity and efficiency analysis of the security and defence technological and industrial base in Spain. Defence and Peace Economics. https://doi.org/10.1080/10242694.2012.663581

McClelland, W. G. (1990). Defence Expenditure and the economics of safety: A comment. Defence Economics. https://doi.org/10.1080/10430719008404679

Ministerio de Defensa. Orden Ministerial 37/2005, de 30 de marzo, por la que se regula el proceso de Planeamiento de la Defensa, BOD § (2005).

Ministerio de Defensa. (2015). Orden Ministerial 60/2015, de 3 de diciembre, por la que se regula el proceso de Planeamiento de la Defensa. BOD.

Ministerio de Defensa. (2019). Delegaciones de Defensa de España. Retrieved October 24, 2019, from https://www.defensa.gob.es/defensa_yo/delegaciones/

Ministerio de Hacienda y Función Pública. (2017). Real Decreto 769/2017, de 28 de julio, por el que se desarrolla la estructura orgánica básica del Ministerio de Hacienda y Función Pública. Boletín Oficial Del Estado, (180, 29 de julio de 2017), 70387-70438.

Ministerio de Política Territorial y Función Pública. (2017). Informe sobre el funcionamiento de los Servicios de la Administración Periférica del Estado en 2017.

Niskanen, W. A. (1971). Bureaucracy and representative government, Chicago: A.

Osman, I. H., Anouze, A. L., \& Emrouznejad, A. (2014). Handbook of Research on Strategic Performance Management and Measurement Using Data Envelopment Analysis (Advances in Logistics, Operations, and Management Science). Business Science Reference.

Ozcan, Y. A., \& Bannick, R. R. (1994). Trends in Department of Defense hospital efficiency. Journal of Medical Systems, 18(2), 69-83. https://doi.org/10.1007/BF00999453

Pollitt, C. (2016a). Advanced introduction to public management and administration. (Edward Elgar Publishing, Ed.). Cheltenham, Glos; Northampton, Massachusetts: Edward Elgar Publishing Ltd.

Pollitt, C. (2016b). Public management: performance, professionalism and politics. International Review of Public Administration. https://doi.org/10.1080/12294659.2016.1189193

R Core Team. (2018). R: A language and environment for statistical computing. Vienna, Austria: R Foundation for Statistical Computing. Retrieved from http://www.rproject.org/

Reppy, J. (1991). On the nature and scope of Defence and Peace Economics: A comment. Defence Economics. https://doi.org/10.1080/10430719108404698

Roll, Y., Golany, B., \& Seroussy, D. (1989). Measuring the efficiency of maintenance units in the Israeli Air Force. European Journal of Operational Research. https://doi.org/10.1016/0377-2217(89)90207-5

Seiford, L. (1996). Data envelopment analysis: The evolution of the state of the art (19781995). Journal of Productivity Analysis, 7(2-3), 99-137. 
https://doi.org/10.1007/BF00157037

Seiford, L. (1997). A bibliography for Data Envelopment Analysis (1978-1996). Annals of Operations Research. https://doi.org/10.1023/A:1018949800069

Shephard, R. W. (1970). Cost and production functions. Princeton, N.J.: Princeton University Press.

Shi, P., Zhang, L. M., Meng, H., \& Sun, Q. W. (2006). Application of data envelopment analysis in optimal allocation of military health resources. Academic Journal of Second Military Medical University.

Simar, L. (2003). Detecting outliers in frontier models: A simple approach. Journal of Productivity Analysis, 20(3), 391-424.

Simar, L., \& Wilson, P. W. (1998). Sensitivity analysis of efficiency scores: How to bootstrap in nonparametric frontier models. Management Science, 44(1), 49-61.

Simar, L., \& Wilson, P. W. (2000). A general methodology for bootstrapping in nonparametric frontier models. Journal of Applied Statistics, 27(6), 779-802.

Simar, L., \& Wilson, P. W. (2002). Non-parametric tests of returns to scale. European Journal of Operational Research, 139(1), 115-132.

Simar, L., \& Wilson, P. W. (2011a). Estimation and inference in nonparametric frontier models: Recent developments and perspectives. Foundations and Trends in Econometrics, 5(3-4), 183-337. https://doi.org/10.1561/0800000020

Simar, L., \& Wilson, P. W. (2011b). Two-stage DEA: caveat emptor. Journal of Productivity Analysis, 36(2), 205-218.

Simar, L., \& Wilson, P. W. (2015). Statistical Approaches for Non-parametric Frontier Models: A Guided Tour. International Statistical Review, 83(1), 77-110. https://doi.org/10.1111/insr.12056

Simm, J., \& Besstremyannaya, G. (2016). Package “rDEA” Title Robust Data Envelopment Analysis (DEA) for $R$. Retrieved from https://github.com/jaak-s/rDEA

Stiglitz, J. E. (1986). Economics of the public sector. W.W. Norton.

Sun, S. (2004). Assessing joint maintenance shops in the Taiwanese Army using data envelopment analysis. Journal of Operations Management. https://doi.org/10.1016/j.jom.2004.01.003

Thanassoulis, E. (2001). Introduction to the theory and application of data envelopment analysis: a foundation text with integrated software. Kluwer Academic Publishers.

Torgersen, A. M., Førsund, F. R., \& Kittelsen, S. A. C. (1996). Slack-adjusted efficiency measures and ranking of efficient units. Journal of Productivity Analysis, 7(4), 379-398. https://doi.org/10.1007/bf00162048

Vega, J. M. (2015). El planeamiento de la defensa en España 2008-2015: Análisis de política pública. Revista de Estudios En Seguridad Internacional. https://doi.org/10.18847/1.2.2

Vilanova, M., Lozano, J. M., \& Arenas, D. (2009). Exploring the nature of the relationship between CSR and competitiveness. In Journal of Business Ethics. https://doi.org/10.1007/s10551-008-9812-2

Wheelock, D. C., \& Wilson, P. W. (2008). Non-parametric, unconditional quantile estimation for efficiency analysis with an application to Federal Reserve check processing 
operations. Journal of Econometrics, 145(1-2), 209-225.

https://doi.org/10.1016/j.jeconom.2008.05.007

Wilson, P. W. (1993). Detecting outliers in deterministic nonparametric frontier models with multiple outputs. Journal of Business and Economic Statistics, 11(3), 319-323.

Wilson, P. W. (1995). Detecting influential observations in data envelopment analysis. Journal of Productivity Analysis, 6, 27-45.

Wilson, P. W. (2008). FEAR: A software package for frontier efficiency analysis with R. Socio-Economic Planning Sciences, 42(4), 247-254.

Worthington, A. C., \& Dollery, B. (2001). Measuring efficiency in local government: An analysis of new south wales municipalities' domestic waste management function. Policy Studies Journal, 29(2), 232-249. 


\section{Tables}

\section{Table 1a. Literature of DEA in Defence: Field of Defence Industry}

\section{Study}

(Bowlin, 1995)

(Barros, 2002)

(Martínez González \& Rueda López, 2013)

(Fonfría \& Duch-Brown, 2014)

(Choi, 2018)

(Jeon \& Yoo, 2019)

\section{Description}

United States. Assesses the financial condition of the aerospace-defence industrial base from 1978 to 1992

Portugal. Use balanced-panel data on the Portuguese defence industries between 1995 and 2000 in relation to 5 companies with information on inputs and outputs (30 observations). Also estimate an output-oriented Malmquist productivity index, based on DEA.

Spain. Performance of the productivity of the main industrial subsectors composing the security and defence technological and industrial base (SDTIB) in Spain from 1996 to 2009. Output-oriented Malmquist TFP index, based on DEA with 2 inputs and 2 outputs with bootstrapping method

Spain. Output-oriented distance function to compute defence contractors' technical efficiency as a measure of performance.

Korea. Efficiency of management in the domestic defence industry is measured using DEA with 2 inputs and two outputs.

Korea. Asses the efficiency of supply chain quality management of defence industries. Multi-stage CCR and BCC DEA models. 
Table 1b. Literature of DEA in Defence: Field of Military Planification

\section{Study}

(Lewin \& Morey, 1981)

(Charnes et al., 1984)

(Bowlin, 1987)

(Roll, Golany, \& Seroussy, 1989)

(Clarke, 1992)

(Bowlin, 2004)

(Sun, 2004)

(Brockett, Cooper, Kumbhakar, Kwinn, \& McCarthy, 2004)

(Farris, Groesbeck, Van Aken, \& Letens, 2006)

(Brence, Kwinn, \& Thomas, 2007)

(Brockett et al., 2008)

(Juan, Huapu, Xu, Xianfeng, \& Huijun, 2014)

\section{Description}

USA. Application of the DEA using data to compare the performance of 43 Navy recruiting district over a three-year period.

USA. 14 aircraft maintenance units in the U.S. Air Force over a period of seven months with 4 outputs and 4 inputs.

USA. DEA analysis of the Air Training Command's in-house real-property maintenance activities' operational efficiency. 3 Inputs and 4 outputs. DEA window analysis.

Israel. Application of DEA to maintenance units in the Israeli Air Force using different reference sets.

USA. A medium-sized application of DEA to Tactical Air Command (TAC) to evaluate the productivity of its 27 vehicle maintenance sections over a four-year period.

USA. Assesses the financial stability of Defences Civil Reserve Air Fleet (CRAF) using DEA BCC model with 7 outputs and 6 inputs.

Taiwan. Performance of joint maintenance shops (JMSs) in the Taiwanese Army over two 6-month periods in 2000. Non-discretionary assurance region (NCNAR) output-oriented DEA models for measuring the performance of JMSs with 8 inputs and 5 outputs.

USA. Three regression approaches to study the effects of Joint versus Service Specific advertising on military recruitment. The third combines regressions with DEA BCC output oriented model.

Belgium. DEA applied to generate objective cross-project comparisons of project duration within an engineering department of the Belgian Armed Forces.

USA. DEA model based on stakeholder interviews with experts towards recruiting process improvement.

USA. Employed several methodologies, including two stochastic frontier regressions, DEA, and, finally, a central tendency OLS regression to analyze the effects of various inputs on military recruiting, with emphasis on Joint vs. ServiceSpecific advertising as it applies to Army recruiting.

China. Propose a model based on DEA (data envelopment analysis) and multiobjective fuzzy decision-making for military transport path selection. 


\section{Table 1c. Literature of DEA in Defence: Field of Resources Management}

\section{Study}

(Bowlin, 1989)

(Ozcan \& Bannick, 1994)

(Bowlin, 1999)

(Harrison \& Ogniewski, 2005)

(Lee, 2006)

(Huo, Zhang, \& Shu, 2006)

(Shi, Zhang, Meng, \& Sun, 2006)

(Fulton, Lasdon, \& McDaniel, 2007)

(Lu \& Chen, 2011)

(Martín Casares, 2013)

(Bastian, Kang, Griffin, \& Fulton, 2016)

(Hanson, 2016)

\section{Description}

USA. DEA radial models applied for U.S. Air Force base level accounting and finance offices (AFOs). Technical and scale efficiencies are measured from 1983 through 1985.

USA. Cross sectional design using longitudinal data to explore the underlying factors associated with differences in hospital technical efficiency in the Department of Defence sector for the years 1988 through 1990 with 2 outputs and 5 inputs.

USA. financial performance of a subset of the defence firms: defence-business segments. DEA BCC model DEA is computed for each year of the 10-year period, 1983-1992 with 3 outputs and 2 inputs.

USA. Efficiency of Veterans Health Administration (VHA) hospitals using a variable-returns to scale, input-oriented, DEA model for the years 1998 and 2001 with 3 inputs and 3 outputs.

Korea. Combines Competing Values Framework (CVF) and DEA to study the effectiveness among 16 Korean military hospitals under the Armed Forces Medical Command for the year 2005.

Evaluate resource allocation efficiency in 9 military institutes for drug and instrument control. DEA CCR and BCC models.

Efficiency of 52 military health service units (MHSUs) was assessed by a variablereturn to scale, input oriented DEA method, combined with other statistical methods.

USA. Evaluates the Army's hospital system located in the United States (17 hospitals and 7 medical centers during the years 2001 through 2003. The total number of observations was 72. Efficiency estimates were included in logarithmic-linear models and compared against stochastic frontier models.

Taiwan. Investigates 28 military financial units (MFUs) responsible for the Armed Forces' financial management, audit of personnel-related expenditure, and the supervision and evaluation of operation and financial management process, in the year 2006. Use an output oriented Slack Based Model (SBM) and a superefficiency-SBM model is used to rank the best performers.

Spain. Modelos DEA CCR y BCC aplicado a 52 delegaciones y subdelegaciones de defensa. Las variables discrecionales seleccionadas contienen 2 inputs y 5 outputs.

USA. BCC input-oriented, variable returns-to-scale DEA model with 4 inputs 2 outputs to compute efficiency for 23 Army hospitals, 12 Air Force hospitals, and 19 Navy hospitals during the period of 2001-2012. Also DEA time window analysis and ordinary least squares (OLS) regression to evaluate the impact of exogenous variables on hospital efficiency.

Norway. Input oriented DEA model with 4 inputs 3 outputs and resampling of original estimates using bootstrap technique for bias correction. Sample of yearly observations from 11 Home Guard districts over the years 2008-2011. 


\section{Table 2. Selection of discretionary variables: inputs and outputs}

\begin{tabular}{|c|c|c|c|c|}
\hline $\mathrm{x}_{1}$ & Input & GASTO & Delegation's annual budget/expenditure \\
\hline $\mathrm{x}_{2}$ & Input & PLANT & Total Number of Workers \\
\hline $\mathrm{y}_{1}$ & Output & SOTRA & Applications processed within less than 2 working days. \\
\hline $\mathrm{y}_{2}$ & Output & CERSV & Certificates of Services rendered sent within 5 working days \\
\hline $\mathrm{y}_{3}$ & Output & CONPR & $\begin{array}{l}\text { Face-to-face consultations attended with a waiting time of less } \\
\text { than } 10 \text { minutes }\end{array}$ \\
\hline $\mathrm{y}_{4}$ & Output & ACTAB & Number of official bulletin board updates per week \\
\hline $\mathrm{y}_{5}$ & Output & PECON & Requests and queries answered within 20 working days \\
\hline y6 & Output & TELEF & Telephone calls with a waiting time of less than 1 minute \\
\hline
\end{tabular}


Table 3. Statistical summary of the variables. Average data for the period

\begin{tabular}{|c|c|c|c|c|c|c|}
\hline Código & $\begin{array}{c}\text { Tipo } \\
\text { Variable }\end{array}$ & Nombre & Mean & $\begin{array}{c}\text { Standard } \\
\text { Deviation }\end{array}$ & Minimum & Maximum \\
\hline x1 & Input & GASTO & $33.754,8$ & $12.570,2$ & $14.190,7$ & $60.845,0$ \\
\hline x2 & Input & PLANT & 46,2 & 25,8 & 15,7 & 130,3 \\
\hline y1 & Output & SOTRA & $17.582,8$ & $17.964,4$ & $1.102,3$ & $72.930,3$ \\
\hline y2 & Output & CERSV & $1.051,5$ & 852,6 & 74,0 & $3.392,7$ \\
\hline y3 & Output & CONPR & $14.305,8$ & $9.055,3$ & $2.229,7$ & $35.141,3$ \\
\hline y4 & Output & ACTAB & 294,9 & 284,9 & 42,7 & $1.335,0$ \\
\hline y5 & Output & PECON & $12.055,5$ & $10.970,2$ & 176,3 & $39.964,7$ \\
\hline y6 & Output & TELEF & $23.381,7$ & $18.039,0$ & $2.422,0$ & $67.579,7$ \\
\hline
\end{tabular}




\section{Table 4a. SDD Efficiency. DEA Models. Year 2015}

\begin{tabular}{|c|c|c|c|c|c|c|}
\hline Delegación & Código & CRS $_{2015}$ & VRS $_{2015}$ & NIRS $_{2015}$ & EE $_{2015}$ & RTS 2015 $^{-1}$ \\
\hline Andalucía & Del-01 & 0.7254 & 1 & 1 & 0.7254 & DRS \\
\hline Aragón & Del-02 & 1 & 1 & 1 & 1 & CRS \\
\hline Asturias & Del-03 & 1 & 1 & 1 & 1 & CRS \\
\hline Baleares & Del-04 & 1 & 1 & 1 & 1 & CRS \\
\hline Canarias & Del-05 & 1 & 1 & 1 & 1 & CRS \\
\hline Cantabria & Del-06 & 1 & 1 & 1 & 1 & CRS \\
\hline Castilla-La Mancha & Del-07 & 1 & 1 & 1 & 1 & CRS \\
\hline Extremadura & Del-11 & 0.6166 & 1 & 0.6166 & 0.6166 & IRS \\
\hline Madrid & Del-13 & 1 & 1 & 1 & 1 & CRS \\
\hline Melilla & Del-14 & 1 & 1 & 1 & 1 & CRS \\
\hline País-Vasco & Del-17 & 0.5703 & 1 & 1 & 0.5703 & DRS \\
\hline Valencia & Del-19 & 1 & 1 & 1 & 1 & CRS \\
\hline Rioja & Del-18 & 0.7343 & 0.8608 & 0.7343 & 0.8530 & IRS \\
\hline Castilla-León & Del-09 & 0.8328 & 0.8374 & 0.8374 & 0.9945 & DRS \\
\hline Navarra & Del-16 & 0.5335 & 0.6763 & 0.5335 & 0.7888 & IRS \\
\hline Murcia & Del-15 & 0.6334 & 0.6508 & 0.6334 & 0.9733 & IRS \\
\hline Ceuta & Del-10 & 0.3937 & 0.5315 & 0.3937 & 0.7406 & IRS \\
\hline Galicia & Del-12 & 0.3913 & 0.4676 & 0.3913 & 0.8369 & IRS \\
\hline Cataluña & Del-08 & 0.3198 & 0.4448 & 0.3198 & 0.7190 & IRS \\
\hline
\end{tabular}




\section{Table 4b. SDD Efficiency. DEA Models. Year 2016}

\begin{tabular}{|c|c|c|c|c|c|c|}
\hline Delegación & Código & $\mathrm{CRS}_{2016}$ & VRS $_{2016}$ & NIRS $_{2016}$ & $\mathbf{E E}_{2016}$ & RTS $_{2016}$ \\
\hline Andalucía & Del-01 & 0.9820 & 1 & 1 & 0.9820 & DRS \\
\hline Aragón & Del-02 & 1 & 1 & 1 & 1 & CRS \\
\hline Asturias & Del-03 & 1 & 1 & 1 & 1 & CRS \\
\hline Baleares & Del-04 & 1 & 1 & 1 & 1 & CRS \\
\hline Canarias & Del-05 & 1 & 1 & 1 & 1 & CRS \\
\hline Cantabria & Del-06 & 0.7485 & 1 & 0.7485 & 0.7485 & IRS \\
\hline Castilla-La Mancha & Del-07 & 0.7632 & 1 & 0.7632 & 0.7632 & IRS \\
\hline Extremadura & Del-09 & 1 & 1 & 1 & 1 & CRS \\
\hline Madrid & Del-11 & 0.5813 & 1 & 0.5813 & 0.5813 & IRS \\
\hline Melilla & Del-13 & 1 & 1 & 1 & 1 & CRS \\
\hline País-Vasco & Del-14 & 1 & 1 & 1 & 1 & CRS \\
\hline Valencia & Del-18 & 0.3853 & 1 & 0.3853 & 0.3853 & IRS \\
\hline Rioja & Del-19 & 1 & 1 & 1 & 1 & CRS \\
\hline Castilla-León & Del-10 & 0.6257 & 0.7734 & 0.6257 & 0.8091 & IRS \\
\hline Navarra & Del-16 & 0.1994 & 0.6936 & 0.1994 & 0.2875 & IRS \\
\hline Murcia & Del-15 & 0.6238 & 0.6889 & 0.6238 & 0.9056 & IRS \\
\hline Ceuta & Del-12 & 0.5418 & 0.5431 & 0.5418 & 0.9976 & IRS \\
\hline Galicia & Del-08 & 0.3770 & 0.4730 & 0.3770 & 0.7970 & IRS \\
\hline Cataluña & Del-17 & 0.1801 & 0.3915 & 0.1801 & 0.4602 & IRS \\
\hline
\end{tabular}




\section{Table 4c. SDD Efficiency. DEA Models. Year 2017}

\begin{tabular}{|c|c|c|c|c|c|c|}
\hline Delegación & Código & $\mathbf{C R S}_{\mathbf{2 0 1 7}}$ & $\mathbf{V R S}_{\mathbf{2 0 1 7}}$ & NIRS 2017 & EE $_{2017}$ & RTS $_{2017}$ \\
\hline Andalucía & Del-01 & 0.63513 & 1 & 1 & 0.63513 & DRS \\
\hline Aragón & Del-02 & 1 & 1 & 1 & 1 & CRS \\
\hline Asturias & Del-03 & 1 & 1 & 1 & 1 & CRS \\
\hline Baleares & Del-04 & 1 & 1 & 1 & 1 & CRS \\
\hline Canarias & Del-06 & 0.82067 & 1 & 0.82067 & 0.82067 & IRS \\
\hline Cantabria & Del-11 & 0.64508 & 1 & 0.64508 & 0.64508 & IRS \\
\hline Castilla-La Mancha & Del-13 & 1 & 1 & 1 & 1 & CRS \\
\hline Extremadura & Del-14 & 1 & 1 & 1 & 1 & CRS \\
\hline Madrid & Del-18 & 0.49416 & 1 & 0.49416 & 0.49416 & IRS \\
\hline Melilla & Del-07 & 0.62798 & 0.99226 & 0.62798 & 0.63287 & IRS \\
\hline País-Vasco & Del-09 & 0.91120 & 0.95288 & 0.91120 & 0.95625 & IRS \\
\hline Valencia & Del-16 & 0.17275 & 0.88612 & 0.17275 & 0.19495 & IRS \\
\hline Rioja & Del-05 & 0.86494 & 0.87411 & 0.86494 & 0.98951 & IRS \\
\hline Castilla-León & Del-19 & 0.76048 & 0.82325 & 0.76048 & 0.92376 & IRS \\
\hline Navarra & Del-10 & 0.66896 & 0.73657 & 0.66896 & 0.90820 & IRS \\
\hline Murcia & Del-12 & 0.68433 & 0.69205 & 0.68433 & 0.98884 & IRS \\
\hline Ceuta & Del-08 & 0.46442 & 0.62738 & 0.46442 & 0.74027 & IRS \\
\hline Galicia & Del-15 & 0.45525 & 0.58172 & 0.45525 & 0.78259 & IRS \\
\hline Cataluña & Del-17 & 0.11937 & 0.53987 & 0.11937 & 0.22112 & IRS \\
\hline & & & & & & \\
\hline
\end{tabular}




\begin{tabular}{|r|c|c|c|c|c|c|c|}
\hline \multicolumn{7}{|c|}{ Table 5. Basic DEA Models 2015-2017. Summary } \\
\hline Year & \multicolumn{2}{|c|}{2015} & \multicolumn{2}{c|}{2016} & \multicolumn{2}{c|}{2017} \\
\hline Eficiencia DEA-CRS & Valor & $\%$ & Valor & $\%$ & Valor & $\%$ \\
\hline Eficiencia media & 0.7764 & 77.6 & 0.7373 & 73.7 & 0.7013 & 70.1 \\
\hline Unidades eficientes & 9 & 47.4 & 8 & 42.1 & 5 & 26.3 \\
\hline Ineficiencia media & 0.5751 & 57.5 & 0.5462 & 54.6 & 0.5946 & 59.5 \\
\hline Unidades ineficientes & 10 & 52.6 & 11 & 57.9 & 14 & 73.7 \\
\hline Eficiencia DEA-VRS & Valor & $\%$ & Valor & $\%$ & Valor & $\%$ \\
\hline Eficiencia media & 0.8668 & 86.7 & 0.8718 & 87.2 & 0.8793 & 87.9 \\
\hline Unidades eficientes & 12 & 63.2 & 13 & 68.4 & 9 & 47.4 \\
\hline Ineficiencia media & 0.6385 & 63.8 & 0.5939 & 59.4 & 0.7706 & 77.1 \\
\hline Unidades ineficientes & 7 & 36.8 & 6 & 31.6 & 10 & 52.6 \\
\hline Eficiencia de Escala & Valor & $\%$ & Valor & $\%$ & Valor & $\%$ \\
\hline Eficiencia media & 0.8852 & 88.5 & 0.8272 & 82.7 & 0.7860 & 78.6 \\
\hline Ineficiencia media & 0.7818 & 78.2 & 0.7016 & 70.2 & 0.7095 & 71.0 \\
\hline Escala de Rendimientos & Valor & $\%$ & Valor & $\%$ & Valor & $\%$ \\
IRS - SSD & 7 & 36.8 & 10 & 52.6 & 13 & 68.4 \\
DRS- SDD & 3 & 15.8 & 1 & 5.3 & 1 & 5.3 \\
CRS-SDD & 9 & 47.4 & 8 & 42.1 & 5 & 26.3 \\
\hline & & & & & & \\
\hline
\end{tabular}




\section{Table 6a. Returns to Scale test. 2015}

\section{Contraste 1}

Ho: CRS

H1: VRS

Estadístico

p-value $48^{(1)}$

$\mathrm{H}_{0}$ reject $48^{(2)}$

$\mathrm{H}_{0}$ level48 ${ }^{(3)}$

$\mathrm{Bw}^{(4)}$

bw_value

\begin{tabular}{|c|}
\hline-0.1148255 \\
\hline 0.06 \\
\hline FALSE \\
\hline-0.116554 \\
\hline$c v$
\end{tabular}

(1)

\section{Contraste 2}

Punto crítico del contraste

(2) Regla de decisión del contraste (sobre la $\mathrm{H}_{0}$ )

(3) Valor de corte del estadístico bootstrap para $\alpha=0,05$

(4) Tipo de bandwith del contraste ${ }^{23}$

(5) Valor estimado para el bandwith

H1: VRS

\begin{tabular}{c|c}
\hline Estadístico & -0.07746639 \\
\hline p-value48 & 0.01 \\
\hline $\mathrm{H}_{0}$ reject48 & TRUE \\
\hline $\mathrm{H}_{0}$ level48 & -0.04702684 \\
\hline $\mathrm{Bw}$ & $\mathrm{cv}$ \\
\hline bw_value & 0.04324725
\end{tabular}




\section{Table 6b. Returns to Scale test. 2016}

\section{Contraste 1}

Ho: CRS

H1: VRS

\section{Contraste 2}

Ho: NIRS

H1: VRS

\begin{tabular}{|c|c|c|c|}
\hline Estadístico & -0.1727677 & Estadístico & -0.1718227 \\
\hline p-value $48^{(1)}$ & 0.03 & p-value 48 & 0.01 \\
\hline $\mathrm{H}_{0}$ reject $48^{(2)}$ & TRUE & $\mathrm{H}_{0}$ reject 48 & TRUE \\
\hline $\mathrm{H}_{0}$ level $48^{(3)}$ & -0.1447807 & $\mathrm{H}_{0}$ level48 & -0.07601149 \\
\hline $\mathrm{Bw}^{(4)}$ & $\mathrm{cV}$ & $\mathrm{Bw}$ & $\mathrm{cv}$ \\
\hline bw_value & 0.08808064 & bw_value & 0.08812047 \\
\hline $\begin{array}{l}\text { Punto crítico d } \\
\text { Regla de decis } \\
\text { Valor de corte } \\
\text { Tipo de bandw }\end{array}$ & $\begin{array}{l}\text { traste } \\
\text { l contraste (so } \\
\text { tadístico boots } \\
\text { l contraste }\end{array}$ & $\begin{array}{l}\left.H_{0}\right) \\
\text { para } \alpha=0,05\end{array}$ & \\
\hline
\end{tabular}




\section{Table 6c. Returns to Scale test. 2017}

\section{Contraste 1}

Ho: CRS

H1: VRS

Estadístico

p-value $48^{(1)}$

$\mathrm{H}_{0}$ reject $48^{(2)}$

$\mathrm{H}_{0}$ level48(3)

$\mathrm{Bw}^{(4)}$

bw_value

\begin{tabular}{c}
-0.2140311 \\
0.01 \\
TRUE \\
-0.1354854 \\
\hline $\mathrm{cv}$
\end{tabular}

0.12426940

(1) Punto crítico del contraste

(2) Regla de decisión del contraste (sobre la $\mathrm{H}_{0}$ )

(3) Valor de corte del estadístico bootstrap para $\alpha=0,05$

(4) Tipo de bandwith del contraste

(5) Valor estimado para el bandwith

\section{Contraste 2}

Ho: NIRS

H1: VRS

Estadístico $\quad-0.1948276$

p-value48 $\quad 0.01$

$\mathrm{H}_{0}$ reject48 TRUE

$\mathrm{H}_{0}$ level48 $\quad-0.07590103$

Bw

$\mathrm{CV}$

0.12504770

bw_value 


\section{Table 7a. DEA-VRS unbiased coefficients 2015}

\begin{tabular}{|c|c|c|c|c|c|c|}
\hline Delegación & $\begin{array}{c}\text { DEA- } \\
\text { VRS }\end{array}$ & $\begin{array}{c}\text { DEA-VRS } \\
\text { Insesgado }\end{array}$ & Sesgo & Varianza & L.I. & L.S. \\
\hline Extremadura & 1 & 1.178 & -0.178 & 0.008 & 1.011 & 1.335 \\
\hline Castilla-La Mancha & 1 & 1.203 & -0.203 & 0.014 & 1.012 & 1.414 \\
\hline Valencia & 1 & 1.204 & -0.204 & 0.016 & 1.009 & 1.456 \\
\hline Andalucía & 1 & 1.218 & -0.218 & 0.023 & 1.012 & 1.541 \\
\hline Canarias & 1 & 1.219 & -0.219 & 0.024 & 1.009 & 1.548 \\
\hline Asturias & 1 & 1.219 & -0.219 & 0.022 & 1.010 & 1.547 \\
\hline País-Vasco & 1 & 1.221 & -0.221 & 0.023 & 1.012 & 1.547 \\
\hline Baleares & 1 & 1.221 & -0.221 & 0.022 & 1.014 & 1.541 \\
\hline Aragón & 1 & 1.222 & -0.222 & 0.022 & 1.007 & 1.548 \\
\hline Madrid & 1 & 1.222 & -0.222 & 0.023 & 1.012 & 1.552 \\
\hline Melilla & 1 & 1.223 & -0.223 & 0.023 & 1.012 & 1.545 \\
\hline Cantabria & 1 & 1.223 & -0.223 & 0.023 & 1.010 & 1.549 \\
\hline Rioja & 1.162 & 1.321 & -0.160 & 0.013 & 1.174 & 1.606 \\
\hline Castilla-León & 1.194 & 1.369 & -0.175 & 0.010 & 1.205 & 1.575 \\
\hline Navarra & 1.479 & 1.673 & -0.194 & 0.015 & 1.492 & 1.938 \\
\hline Murcia & 1.536 & 1.730 & -0.194 & 0.012 & 1.548 & 1.968 \\
\hline Ceuta & 1.881 & 2.090 & -0.209 & 0.012 & 1.902 & 2.328 \\
\hline Galicia & 2.139 & 2.452 & -0.313 & 0.028 & 2.158 & 2.803 \\
\hline Cataluña & 2.248 & 2.544 & -0.296 & 0.022 & 2.277 & 2.824 \\
\hline
\end{tabular}




\section{Table 7b. DEA-VRS unbiased coefficients 2016}

\begin{tabular}{|c|c|c|c|c|c|c|}
\hline Delegación & $\begin{array}{c}\text { DEA- } \\
\text { VRS }\end{array}$ & $\begin{array}{c}\text { DEA-VRS } \\
\text { Insesgado }\end{array}$ & Sesgo & Varianza & L.I. & L.S. \\
\hline Castilla-La Mancha & 1 & 1.123 & -0.123 & 0.003 & 1.013 & 1.236 \\
\hline Rioja & 1 & 1.149 & -0.149 & 0.007 & 1.010 & 1.343 \\
\hline Extremadura & 1 & 1.180 & -0.180 & 0.009 & 1.012 & 1.344 \\
\hline Valencia & 1 & 1.184 & -0.184 & 0.011 & 1.010 & 1.410 \\
\hline Canarias & 1 & 1.188 & -0.188 & 0.012 & 1.011 & 1.444 \\
\hline Cantabria & 1 & 1.202 & -0.202 & 0.013 & 1.010 & 1.400 \\
\hline Castilla-León & 1 & 1.226 & -0.226 & 0.024 & 1.013 & 1.574 \\
\hline Baleares & 1 & 1.226 & -0.226 & 0.024 & 1.011 & 1.574 \\
\hline Asturias & 1 & 1.226 & -0.226 & 0.024 & 1.012 & 1.575 \\
\hline Andalucía & 1 & 1.229 & -0.229 & 0.025 & 1.009 & 1.587 \\
\hline Aragón & 1 & 1.230 & -0.230 & 0.024 & 1.011 & 1.571 \\
\hline Melilla & 1 & 1.231 & -0.231 & 0.024 & 1.010 & 1.574 \\
\hline Madrid & 1 & 1.234 & -0.234 & 0.025 & 1.011 & 1.585 \\
\hline Ceuta & 1.293 & 1.444 & -0.151 & 0.005 & 1.309 & 1.592 \\
\hline Navarra & 1.442 & 1.638 & -0.196 & 0.018 & 1.451 & 1.923 \\
\hline Murcia & 1.452 & 1.639 & -0.187 & 0.012 & 1.467 & 1.863 \\
\hline Galicia & 1.841 & 2.138 & -0.297 & 0.032 & 1.865 & 2.580 \\
\hline Cataluña & 2.114 & 2.373 & -0.259 & 0.019 & 2.139 & 2.655 \\
\hline País-Vasco & 2.554 & 2.884 & -0.330 & 0.045 & 2.572 & 3.322 \\
\hline
\end{tabular}




\section{Table 7c. DEA-VRS unbiased coefficients 2017}

\begin{tabular}{|c|c|c|c|c|c|c|}
\hline Delegación & $\begin{array}{c}\text { DEA- } \\
\text { VRS }\end{array}$ & $\begin{array}{c}\text { DEA-VRS } \\
\text { Insesgado }\end{array}$ & Sesgo & Varianza & L.I. & L.S. \\
\hline Castilla-La Mancha & 1.008 & 1.103 & -0.096 & 0.004 & 1.015 & 1.237 \\
\hline Rioja & 1 & 1.117 & -0.117 & 0.006 & 1.007 & 1.318 \\
\hline Castilla-León & 1.049 & 1.138 & -0.088 & 0.003 & 1.055 & 1.260 \\
\hline Cantabria & 1 & 1.144 & -0.144 & 0.009 & 1.007 & 1.345 \\
\hline Extremadura & 1 & 1.154 & -0.154 & 0.013 & 1.006 & 1.377 \\
\hline Baleares & 1 & 1.160 & -0.160 & 0.017 & 1.007 & 1.454 \\
\hline Madrid & 1 & 1.160 & -0.160 & 0.017 & 1.006 & 1.455 \\
\hline Aragón & 1 & 1.162 & -0.162 & 0.017 & 1.007 & 1.453 \\
\hline Melilla & 1 & 1.162 & -0.162 & 0.016 & 1.007 & 1.448 \\
\hline Asturias & 1 & 1.164 & -0.164 & 0.017 & 1.007 & 1.453 \\
\hline Andalucía & 1 & 1.168 & -0.168 & 0.017 & 1.006 & 1.451 \\
\hline Navarra & 1.129 & 1.223 & -0.094 & 0.004 & 1.135 & 1.364 \\
\hline Canarias & 1.144 & 1.255 & -0.111 & 0.007 & 1.152 & 1.485 \\
\hline Valencia & 1.215 & 1.332 & -0.117 & 0.007 & 1.223 & 1.539 \\
\hline Ceuta & 1.358 & 1.489 & -0.131 & 0.006 & 1.367 & 1.666 \\
\hline Galicia & 1.445 & 1.592 & -0.147 & 0.011 & 1.454 & 1.860 \\
\hline Cataluña & 1.594 & 1.724 & -0.130 & 0.005 & 1.603 & 1.868 \\
\hline Murcia & 1.719 & 1.861 & -0.142 & 0.007 & 1.729 & 2.044 \\
\hline País-Vasco & 1.852 & 2.020 & -0.168 & 0.018 & 1.863 & 2.365 \\
\hline
\end{tabular}




\section{Appendice}

Appendice I. Template designed for the collection of data from each Defence Delegation

\begin{tabular}{|c|c|c|c|c|c|c|}
\hline DELEGATION: & \multicolumn{6}{|c|}{ (LOCATION) } \\
\hline \multirow{2}{*}{ 1. ACTIONS } & \multicolumn{2}{|c|}{ Year: 20} & \multicolumn{2}{|c|}{ Year: 20} & \multicolumn{2}{|c|}{ Year: 20} \\
\hline & $\begin{array}{l}\text { Within } \\
\text { deadline }\end{array}$ & $\begin{array}{c}\text { Out of } \\
\text { deadline }\end{array}$ & $\begin{array}{c}\text { Within } \\
\text { deadline }\end{array}$ & $\begin{array}{c}\text { Out of } \\
\text { deadline }\end{array}$ & $\begin{array}{l}\text { Within } \\
\text { deadline }\end{array}$ & $\begin{array}{c}\text { Out of } \\
\text { deadline }\end{array}$ \\
\hline 1.1 Documentation Procedures (1) & (No.) & (No.) & (No.) & (No.) & (No.) & (No.) \\
\hline 1.2 Certifications of Services Provided (2) & (No.) & (No.) & (No.) & (No.) & (No.) & (No.) \\
\hline 1.3 Complaints and suggestions (3) & (No.) & (No.) & (No.) & (No.) & (No.) & (No.) \\
\hline 1.4 Attendance (4) & (No.) & (No.) & (No.) & (No.) & (No.) & (No.) \\
\hline 1.5 Updates Bulletin Board (5) & (No.) & (No.) & (No.) & (No.) & (No.) & (No.) \\
\hline 1.6 Requests and queries (5) & (No.) & (No.) & (No.) & (No.) & (No.) & (No.) \\
\hline 1.7 Telephone calls (6) & (No.) & (No.) & (No.) & (No.) & (No.) & (No.) \\
\hline 1.8 Intranet Waiting time (7) & (No.) & (No.) & (No.) & (No.) & (No.) & (No.) \\
\hline 2. PERSONNEL & \multicolumn{2}{|c|}{ Year: 20} & \multicolumn{2}{|c|}{ Year: 20} & \multicolumn{2}{|c|}{ Year: 20} \\
\hline 2.1.1 Officers & \multirow{3}{*}{\multicolumn{2}{|c|}{$\begin{array}{l}\text { (No.) } \\
\text { (No.) } \\
\text { (No.) }\end{array}$}} & \multirow{3}{*}{\multicolumn{2}{|c|}{$\begin{array}{l}\text { (No.) } \\
\text { (No.) } \\
\text { (No.) }\end{array}$}} & \multirow{3}{*}{\multicolumn{2}{|c|}{$\begin{array}{l}\text { (No.) } \\
\text { (No.) } \\
\text { (No.) } \\
\end{array}$}} \\
\hline 2.1.2 Non-Commissioned Officers & & & & & & \\
\hline 2.1.3 Troop & & & & & & \\
\hline 2.1 Total Military Personnel & \multicolumn{2}{|c|}{ (sum) } & \multicolumn{2}{|c|}{ (sum) } & \multicolumn{2}{|c|}{ (sum) } \\
\hline 2.2.1 Civil Servant & \multirow{2}{*}{\multicolumn{2}{|c|}{$\begin{array}{l}\text { (No.) } \\
\text { (No.) }\end{array}$}} & \multirow{2}{*}{\multicolumn{2}{|c|}{$\begin{array}{l}\text { (No.) } \\
\text { (No.) }\end{array}$}} & \multirow{2}{*}{\multicolumn{2}{|c|}{$\begin{array}{l}\text { (No.) } \\
\text { (No.) }\end{array}$}} \\
\hline 2.2.2 Personnel Laboral & & & & & & \\
\hline 2.2 Total Civilian Personnel & \multicolumn{2}{|c|}{ (sum) } & \multicolumn{2}{|c|}{ (sum) } & \multicolumn{2}{|c|}{ (sum) } \\
\hline $\begin{array}{l}\text { 3. ALLOCATED BUDGET / } \\
\text { EXPENDITURE }\end{array}$ & \multicolumn{2}{|c|}{ Year: 20__ } & \multicolumn{2}{|c|}{ Year: 20} & \multicolumn{2}{|c|}{ Year: 20} \\
\hline 3.1 Allocated budget / expenditure $(€)$ & \multicolumn{2}{|c|}{ (euros) } & \multicolumn{2}{|c|}{ (euros) } & \multicolumn{2}{|c|}{ (euros) } \\
\hline
\end{tabular}

(1) Applications processed within less than two working days are considered to be in time.

(2) Certificates of Services rendered sent within 5 working days are considered in due time.

(3) Complaints and suggestions answered within a period of less than 15 working days are considered within the deadline.

(4) In-person consultations attended with a waiting time of less than 10 minutes are considered within the deadline.

(5) Updates to the official bulletin board per week are considered on time.

(6) Requests and queries answered within a period of less than 20 working days are considered within the deadline..

(7) Telephone calls with a waiting time of less than one minute are considered within the time limit.

(8) The accesses to the computer network of the Department with a waiting time of less than 20 minutes are considered within the term. 